\title{
Radiosensitizing Effect of Novel Phenylpyrimidine Derivatives on Human Lung Cancer Cells via Cell Cycle Perturbation\$
}

\author{
Seung-Youn Jung, ${ }^{1}$ Ky-Youb Nam, ${ }^{1}$ Jeong-In Park, Kyung-Hee Song, (DJiyeon Ahn, \\ (1) Jong Kuk Park, Hong-Duck Um, (1)Sang-Gu Hwang, Sang Un Choi, \\ and (1) Jie-Young Song
}

Division of Radiation Biomedical Research, Korea Institute of Radiological \& Medical Sciences, Seoul, Republic of Korea (S.-Y.J., J.-I.P., K.-H.S., J.A., J.K.P., H.-D.U., S.-G.H., J.-Y.S.); Research Center, Pharos I\&BT Co., Ltd., Anyang, Republic of Korea (K.-Y.N.); Graduate School of Pharmaceutical Sciences, College of Pharmacy, Ewha Womans University, Seoul, Republic of Korea (K.-H.S.); and Bio and Drug Discovery Division, Korea Research Institute of Chemical Technology, Daejeon, Republic of Korea (S.U.C.)

Received February 24, 2019; accepted June 24, 2019

\section{ABSTRACT}

Radiotherapy is one of the most common treatments for cancer, but radioresistance and injury to normal tissue are considered major obstacles to successful radiotherapy. Thus, there is an urgent need to develop radiosensitizers to improve the therapeutic outcomes of radiotherapy in cancer patients. Our previous efforts to identify novel radiosensitizers, using high-throughput screening targeting p53 and Nrf2 revealed a promising $N$-phenylpyrimidin-2-amine (PPA) lead compound. In the present study, 17 derivatives of this lead compound were examined, and it was found that 4-(4-fluorophenyl)-N(4-nitrophenyl)-6-phenylpyrimidin-2-amine (PPA5), 4-((4-(4fluorophenyl)pyrimidin-2-yl)amino)-3-methoxy-N-methyl -benzamide (PPA13), 4-((4-(4-fluorophenyl)pyrimidin-2-yl)amino)benzenesulfonamide (PPA14), 4-((4-(2-chlorophenyl)pyrimidin-2-yl) amino)benzenesulfonamide (PPA15), and 4-((4-(2-chlorophenyl) pyrimidin-2-yl)amino)-N-methylbenzamide (PPA17) inhibited cell viability by more than $50 \%$, with a marked increase in the proportion of cells arrested at the $\mathrm{G}_{2} / \mathrm{M}$ phase of cell cycle. Among these compounds, PPA15 markedly increased the sub- $\mathrm{G}_{1}$ cell population and increased the levels of cyclin B1 and the phosphorylation levels of cyclin-dependent kinase (CDK) 1. Combined treatment with radiation and PPA14 or PPA15 significantly decreased clonogenic survival. An in vitro kinase assay revealed that PPA15 inhibited multiple CDKs involved in cell cycle regulation. Compared with drug or radiation treatment alone, combined treatment with PPA15 and radiation resulted in the suppression of A549 tumor growth in mice by $59.5 \%$ and $52.7 \%$, respectively. Treatment with PPA 15 alone directly inhibited tumor growth by $25.7 \%$. These findings suggest that the novel pan CDK inhibitor, PPA15, may be a promising treatment to improve the effectiveness of radiotherapy for the treatment of cancer.

\section{SIGNIFICANCE STATEMENT}

Several inhibitors of CDK have been successfully evaluated in combination with other chemotherapeutics in clinical trials, but negative side effects have partially restricted their clinical use. In this study, we identified a novel pan-CDK inhibitor to increase radiosensitivity, and we hope this work will encourage the development of promising small-molecule radiosensitizers.

\section{Introduction}

Radiotherapy is used to treat up to $50 \%$ of cancer patients, making it the most common therapeutic strategy for cancer treatment (Chi et al., 2018). However, a considerable number of patients undergoing radiotherapy develop radioresistance and experience recurrence, with a consequent deterioration of the prognosis and a decreased survival rate. Recent advances in molecular and cellular biology have revealed that several

This work was supported by the National Research Foundation of Korea [Grant NRF-2017M2A2A7A01019214] and the Korea Institute of Radiological and Medical Sciences, funded by the Ministry of Science and ICT, Republic of Korea [Grant 50531-2018].

${ }^{1}$ S.-Y.J. and K.-Y.N. contributed equally to this work.

https://doi.org/10.1124/jpet.119.257717.

S This article has supplemental material available at jpet.aspetjournals.org. diverse factors play a role in the acquisition of radioresistance in human cancers: the number and intrinsic radiosensitivity of cancer stem cells, tumor hypoxia and reoxygenation during treatment, repopulation between radiotherapy fractions and redistribution of surviving cells, and DNA damage repair (Petersen et al., 2001; Krause et al., 2011; Yaromina et al., 2011; Baumann et al., 2016; Sharma et al., 2016). Therefore, the development of effective radiation response modifiers that target the previously described relevant pathways is extremely important for increasing the efficacy of radiotherapy (Harrington et al., 2011).

Cyclin-dependent kinases (CDKs) are a family of serinethreonine kinases that play a critical role in cell cycle regulation (CDK1, 2, 4, and 6), transcriptional regulation (CDK7, 8, and 9), and neuronal function (CDK5) (Asghar et al., 2015).

ABBREVIATIONS: brs, broad singlet; CDK, cyclin-dependent kinase; $d$, doublet; DMSO- $\mathrm{d}_{6}$, hexadeutero-DMSO; $\mathrm{m}$, multiplet; $\mathrm{m} / \mathrm{z}$, mass-tocharge ratio; PARP, poly (ADP-ribose) polymerase; PPA, $N$-phenylpyrimidin-2-amine; s, singlet; t, triplet. 
Aberrations in CDKs, affecting cell cycle control and their cyclin partners, have been observed in various cancers, usually characterized by dysregulated cell division (Malumbres and Barbacid, 2001). Thus, CDKs have long been regarded as attractive targets for the development of pharmacological inhibitors for cancer treatment. Many early, first-generation, nonselective CDK inhibitors showed toxicity and poor efficacy; however, the recent development of multitarget CDK inhibitors and more selective targeting of CDK4/6 inhibitors have led to the approval of palbociclib for the treatment of breast cancer (O'Leary et al., 2016; Sherr et al., 2016).

In our attempts to identify novel radiosensitizers, we performed cell-based screening using a luciferase-reporter assay system targeting tumor protein 53 (p53; TP53), nuclear factor (erythroid-derived 2)-like 2 (Nrf2; NFE2L2), and transforming growth factor $\beta$ (Lee et al., 2012; Lim et al., 2012; Jung et al., 2015; Kang et al., 2015). A chemical library of 14,600 compounds was screened, and we identified a hit compound containing an aniline-pyrimidine scaffold, as shown in Table 1. These chemotypes are known to be promiscuous kinase inhibitors and have been heavily patented. Therefore, in this study, we synthesized several derivatives of the hit compound and determined their biologic activities and underlying mechanisms.

\section{Materials and Methods}

General Methods for Chemistry. All reactions involving airsensitive reagents were performed in inert atmosphere $\left(\mathrm{N}_{2}\right.$ or $\left.\mathrm{Ar}\right)$ using syringe-septum cap techniques. All glassware was oven dried prior to use. Mass spectra were recorded on a JMS-700 MStation (EI mode; JEOL Ltd., Tokyo, Japan). The ${ }^{1} \mathrm{H}$ NMR spectra were recorded on an Avance-500 (Bruker Daltonics Inc., Billerica, MA). Chemical shifts are expressed as $\delta$ values relative to trimethylsilyl as the internal standard, $J$ values are expressed in Hertz, and spectra were recorded in $\mathrm{CDCl}_{3}$ or hexadeutero-DMSO [(DMSO-d $\mathrm{d}_{6}$; SigmaAldrich, St. Louis, MO]. Multiplicities of signals are indicated by the following symbols: $\mathrm{s}$ (singlet), $\mathrm{d}$ (doublet), $\mathrm{t}$ (triplet), $\mathrm{m}$ (multiplet), and brs (broad singlet). All reagents used were acquired from Sigma-Aldrich and were used without further purification unless otherwise stated. The following $N$-phenylpyrimidin-2-amine (PPA) compounds were purchased from ChemBridge (San Diego, CA); 4-(4fluoruphenyl)-N-phenylpyrimidin-2-amine (PPA1), N-(4-methoxyphenyl)-4-phenylpyrimidin-2-amine (PPA2), N-phenyl-4-(pyridine2-yl)pyrimidin-2-amine (PPA3), 6-chloro-N-(4-nitophenyl)-4-phenylquinazolin-2-amine (PPA4), 4-(4-fluorophenyl)-N-(4-nitrophenyl)-6phenylpyrimidin-2-amine (PPA5), N-(4-((4-methyl-6-(phenylamino) pyrimidin-2-yl)amino)phenyl) acetamide (PPA6), (3-((6-chloro-4phenylqyinazolin-2-yl)amino)phenyl)((morpholino) methanone (PPA7), and Ethyl 4-((4-(4-fluotophenyl)-6-phenylpyrimidin-2-yl)amino) benzoate (PPA8).

PPA9 Compound: 4-(4-Fluorophenyl)- $N$-(4-Nitrophenyl) Pyrimidin-2-Amine. ${ }^{1} \mathrm{H}$ NMR (DMSO- $\left.\mathrm{d}_{6}, 400 \mathrm{MHz}\right): \delta=10.5(1 \mathrm{H}$, s), $8.68(1 \mathrm{H}, \mathrm{d}, J=4.0 \mathrm{~Hz}), 8.52(1 \mathrm{H}, \mathrm{s}), 8.23-8.32(3 \mathrm{H}, \mathrm{m}), 8.10(2 \mathrm{H}, \mathrm{d}$, $J=8.0 \mathrm{~Hz}), 7.62(1 \mathrm{H}, \mathrm{d}, J=8.0 \mathrm{~Hz}), 7.42(2 \mathrm{H}, \mathrm{t}, J=8.0 \mathrm{~Hz})$. Mass $\left(\mathrm{FAB}^{+}\right)$: mass-to-charge ratio $(\mathrm{m} / z) 311.1\left(\mathrm{MH}^{+}\right)$. Yellow solid.

PPA10 Compound: 4-(4-Fluorophenyl)-N,6-Diphenylpyrimidin2-Amine. ${ }^{1} \mathrm{H}$ NMR (DMSO- $\mathrm{d}_{6}, 400 \mathrm{MHz}$ ): $\delta=9.75$ (1H, s), 8.38-8.42 $(2 \mathrm{H}, \mathrm{m}), 8.32-8.34(2 \mathrm{H}, \mathrm{m}), 8.00(1 \mathrm{H}, \mathrm{s}), 7.91(2 \mathrm{H}, \mathrm{d}, J=8.0 \mathrm{~Hz})$, $7.57-7.59(3 \mathrm{H}, \mathrm{m}), 7.42(2 \mathrm{H}, \mathrm{t}, J=10.0 \mathrm{~Hz}), 7.35(2 \mathrm{H}, \mathrm{t}, J=8.0 \mathrm{~Hz})$, $6.99(1 \mathrm{H}, \mathrm{t}, J=8.0 \mathrm{~Hz})$. Mass $\left(\mathrm{FAB}^{+}\right): \mathrm{m} / z 342.1\left(\mathrm{MH}^{+}\right)$. Yellow solid.

PPA11 Compound: $\boldsymbol{N}$-(4-((4-(4-Fluorophenyl)Pyrimidin-2-yl) Amino)Phenyl)Acetamide. ${ }^{1} \mathrm{H} \mathrm{NMR}\left(\mathrm{CDCl}_{3}, 400 \mathrm{MHz}\right): \delta=$ 8.35-8.40 (3H, m), $7.54(2 \mathrm{H}, \mathrm{d}, J=8.0 \mathrm{~Hz}), 7.37(2 \mathrm{H}, \mathrm{d}, J=12.0$ $\mathrm{Hz}), 7.18(1 \mathrm{H}, \mathrm{brs}), 7.13(2 \mathrm{H}, \mathrm{t}, J=8.0 \mathrm{~Hz}), 6.75(1 \mathrm{H}, \mathrm{brs}), 6.53(1 \mathrm{H}, \mathrm{d}$, $J=8.0 \mathrm{~Hz}), 2.20(3 \mathrm{H}, \mathrm{s})$. Mass $\left(\mathrm{FAB}^{+}\right): m / z 323.1\left(\mathrm{MH}^{+}\right)$. Yellow solid.
PPA12 Compound: 4-(4-Fluorophenyl)-N-(4-(4-Methylpiperazin1-yl)Phenyl)Pyrimidin-2-Amine. ${ }^{1} \mathrm{H}$ NMR $\left(\mathrm{CDCl}_{3}, 400 \mathrm{MHz}\right): \delta=$ 8.35-8.41 (2H, m), $8.30(1 \mathrm{H}, \mathrm{d}, J=4.0 \mathrm{~Hz}), 7.24-7.28(2 \mathrm{H}, \mathrm{m}), 7.13(2 \mathrm{H}$, t, $J=8.0 \mathrm{~Hz}), 6.97(2 \mathrm{H}, \mathrm{d}, J=8.0 \mathrm{~Hz}), 6.68(1 \mathrm{H}, \mathrm{brs}), 6.45(1 \mathrm{H}, \mathrm{d}, J=4.0$ $\mathrm{Hz}), 3.23(4 \mathrm{H}, \mathrm{t}, J=6.0 \mathrm{~Hz}), 2.60(4 \mathrm{H}, \mathrm{d}, J=6.0 \mathrm{~Hz}), 2.37(3 \mathrm{H}, \mathrm{s})$. Mass $\left(\mathrm{FAB}^{+}\right): \mathrm{m} / z 364.2\left(\mathrm{MH}^{+}\right)$. Yellow solid.

PPA13 Compound: 4-((4-(4-Fluorophenyl)Pyrimidin-2-yl) Amino)-3-Methoxy- $\boldsymbol{N}$-Methyl-Benzamide. ${ }^{1} \mathrm{H} \mathrm{NMR}\left(\mathrm{CDCl}_{3}, 400\right.$ $\mathrm{MHz}): \delta=8.35-8.41(2 \mathrm{H}, \mathrm{m}), 8.30(1 \mathrm{H}, \mathrm{d}, J=4.0 \mathrm{~Hz}), 7.24-7.28(2 \mathrm{H}$, $\mathrm{m}), 7.13(2 \mathrm{H}, \mathrm{t}, J=8.0 \mathrm{~Hz}), 6.97(2 \mathrm{H}, \mathrm{d}, J=8.0 \mathrm{~Hz}), 6.68(1 \mathrm{H}, \mathrm{brs}), 6.45$ $(1 \mathrm{H}, \mathrm{d}, J=4.0 \mathrm{~Hz}), 3.23(4 \mathrm{H}, \mathrm{t}, J=6.0 \mathrm{~Hz}), 2.60(4 \mathrm{H}, \mathrm{d}, J=6.0 \mathrm{~Hz})$, $2.37(3 \mathrm{H}, \mathrm{s})$. Mass $\left(\mathrm{FAB}^{+}\right): \mathrm{m} / z 353.1\left(\mathrm{MH}^{+}\right)$. Yellow solid.

PPA14 Compound: 4-((4-(4-Fluorophenyl)Pyrimidin-2-yl) Amino)Benzenesulfonamide. ${ }^{1} \mathrm{H}$ NMR (DMSO- $\left.\mathrm{d}_{6}, 400 \mathrm{MHz}\right): \delta=$ $10.1(1 \mathrm{H}, \mathrm{s}), 8.62(1 \mathrm{H}, \mathrm{d}, J=4.0 \mathrm{~Hz}), 8.26(2 \mathrm{H}$, double doublet, $J=10.0$, $4.0 \mathrm{~Hz}), 7.99(2 \mathrm{H}, \mathrm{d}, J=8.0 \mathrm{~Hz}), 7.77(2 \mathrm{H}, \mathrm{d}, J=8.0 \mathrm{~Hz}), 7.52(1 \mathrm{H}, \mathrm{d}$, $J=4.0 \mathrm{~Hz}), 7.41(2 \mathrm{H}, \mathrm{t}, J=10.0 \mathrm{~Hz}), 7.19(2 \mathrm{H}, \mathrm{s})$. Mass $\left(\mathrm{FAB}^{+}\right): \mathrm{m} / z$ $345.1\left(\mathrm{MH}^{+}\right)$. Bright yellow solid.

PPA15 Compound: 4-((4-(2-Chlorophenyl)Pyrimidin-2-yl) Smino)Benzenesulfonamide. ${ }^{1} \mathrm{H}$ NMR (DMSO- $\left.\mathrm{d}_{6}, 400 \mathrm{MHz}\right): \delta=$ $10.2(1 \mathrm{H}, \mathrm{s}), 8.66(1 \mathrm{H}, \mathrm{d}, J=8.0 \mathrm{~Hz}), 7.96(2 \mathrm{H}, \mathrm{d}, J=8.0 \mathrm{~Hz}), 7.72(2 \mathrm{H}$, $\mathrm{d}, J=8.0 \mathrm{~Hz}), 7.62-7.69(2 \mathrm{H}, \mathrm{m}), 7.52-7.56(2 \mathrm{H}, \mathrm{m}), 7.20(1 \mathrm{H}, \mathrm{d}, J=$ $4.0 \mathrm{~Hz}), 7.28(2 \mathrm{H}, \mathrm{s})$. Mass $\left(\mathrm{FAB}^{+}\right): \mathrm{m} / z 361.0\left(\mathrm{MH}^{+}\right)$. Yellow solid.

PPA16 Compound: 4-(2-Chlorophenyl)- $\mathbf{N}$-(3-Nitrophenyl) Pyrimidin-2-Amine. ${ }^{1} \mathrm{H}$ NMR (DMSO- $\left.\mathrm{d}_{6}, 400 \mathrm{MHz}\right): \delta=10.3(1 \mathrm{H}$, s), $8.95(1 \mathrm{H}, \mathrm{s}), 8.69(1 \mathrm{H}, \mathrm{d}, J=4.0 \mathrm{~Hz}), 8.08-8.15(1 \mathrm{H}, \mathrm{m}), 7.79-7.81$ $(1 \mathrm{H}, \mathrm{m}), 7.70-7.73(1 \mathrm{H}, \mathrm{m}), 7.63-7.66(1 \mathrm{H}, \mathrm{m}), 7.52-7.59(3 \mathrm{H}, \mathrm{m}), 7.24$ $(1 \mathrm{H}, \mathrm{d}, J=4.0 \mathrm{~Hz})$. Mass $\left(\mathrm{FAB}^{+}\right): \mathrm{m} / z 327.1\left(\mathrm{MH}^{+}\right)$. Green solid.

PPA17 Compound: 4-((4-(2-Chlorophenyl)Pyrimidin-2-yl) Amino)- $\boldsymbol{N}$-Methylbenzamide. ${ }^{1} \mathrm{H}$ NMR (DMSO- $\left.\mathrm{d}_{6}, 400 \mathrm{MHz}\right): \delta=$ $10.0(1 \mathrm{H}, \mathrm{s}), 8.64(1 \mathrm{H}, \mathrm{d}, J=8.0 \mathrm{~Hz}), 8.21-8.26(1 \mathrm{H}, \mathrm{m}), 7.87(2 \mathrm{H}, \mathrm{d}, J=$ $12.0 \mathrm{~Hz}), 7.76(2 \mathrm{H}, \mathrm{d}, J=8.0 \mathrm{~Hz}), 7.62-7.68(2 \mathrm{H}, \mathrm{m}), 7.51-7.54(2 \mathrm{H}, \mathrm{m})$, $7.16(1 \mathrm{H}, \mathrm{d}, J=4.0 \mathrm{~Hz}), 2.75(3 \mathrm{H}, \mathrm{d}, J=4.0 \mathrm{~Hz})$. Mass $\left(\mathrm{FAB}^{+}\right): \mathrm{m} / z$ $339.1\left(\mathrm{MH}^{+}\right)$. White solid.

Cell Culture and Treatment. Human lung carcinoma A549 and H1299 cells, prostate carcinoma DU 145 cells, ovarian carcinoma SKOV3 cells, glioblastoma U-87 MG cells, and breast cancer MDAMB-231 cells were purchased from American Type Culture Collection (Manassas, VA). The cells were grown in RPMI 1640 or Dulbecco's modified Eagle's medium (Welgene, Daegu, Korea) supplemented with $10 \% \mathrm{FBS}, 100 \mathrm{IU} / \mathrm{ml}$ penicillin, and $100 \mu \mathrm{g} / \mathrm{ml}$ streptomycin (Invitrogen, Carlsbad, CA). Cells were maintained at $37^{\circ} \mathrm{C}$ in a humidified atmosphere containing $5 \% \mathrm{CO}_{2}$. All compounds were dissolved in DMSO and the final concentration of DMSO did not exceed $0.1 \%(\mathrm{v} / \mathrm{v})$. All controls were treated with DMSO only.

Cell Viability Assay. Cell viability was evaluated with 3-(4,5dimethylthiazol-2-yl)-2,5-diphenyltetrazolium bromide (SigmaAldrich) colorimetric growth assay. Briefly, cells were seeded in 96well plates at a density of 1000 cells/well and treated with the indicated compounds for 72 hours. All tested substances were dissolved in DMSO and diluted to the indicated final test concentrations. 3-(4,5-Dimethylthiazol-2-yl)-2,5-diphenyltetrazolium bromide $(5 \mathrm{mg} / \mathrm{ml})$ was added to the cells, and they were further incubated for 4 hours at $37^{\circ} \mathrm{C}$. The supernatant was removed, $100 \mu \mathrm{l}$ DMSO was added, and then the absorbance was measured at $540 \mathrm{~nm}$ using a microplate reader (Multiskan EX; Thermo Fisher Scientific, Waltham, MA). All experiments were performed in triplicate.

Apoptosis Assay. Apoptosis was evaluated by measuring the proportion of annexin-positive cells. Cells were labeled with allophycocyanin (APC)-conjugated annexin $\mathrm{V}$ and propidium iodide in binding buffer (BD Biosciences, San Diego, CA) according to the manufacturer's instructions and analyzed using a FACSCalibur Flow Cytometer (BD Biosciences). For each sample, at least 10,000 events/sample were acquired. The percentage of annexin V-APC-positive cells was analyzed with FlowJo software version 7.2.5 (Tree Star Inc., Ashland, OR).

Cell Cycle Analysis. A549 cells were seeded in six-well plates at a density of 10,000 cells $/ \mathrm{cm}^{2}$ and treated under the indicated 
Jung et al.

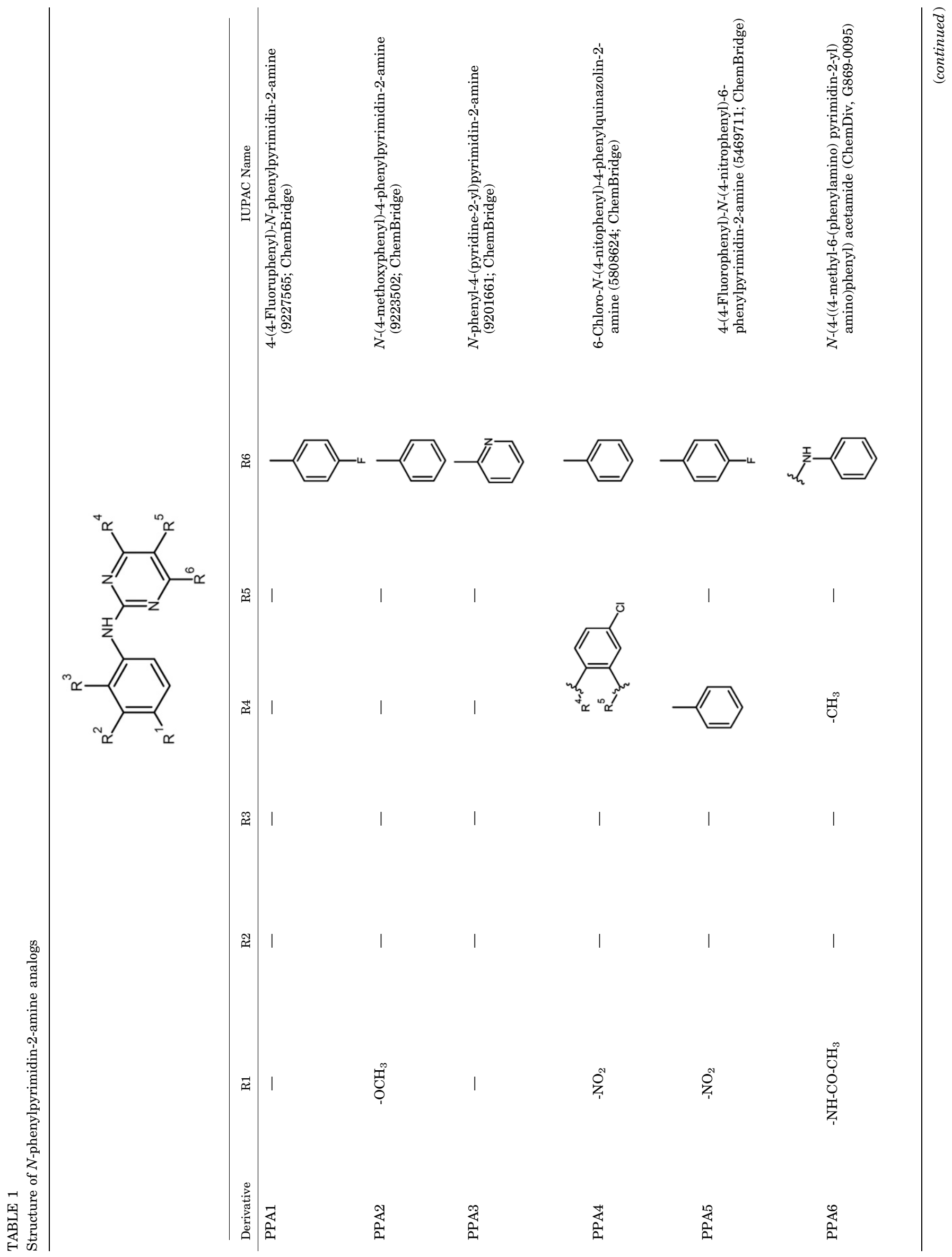




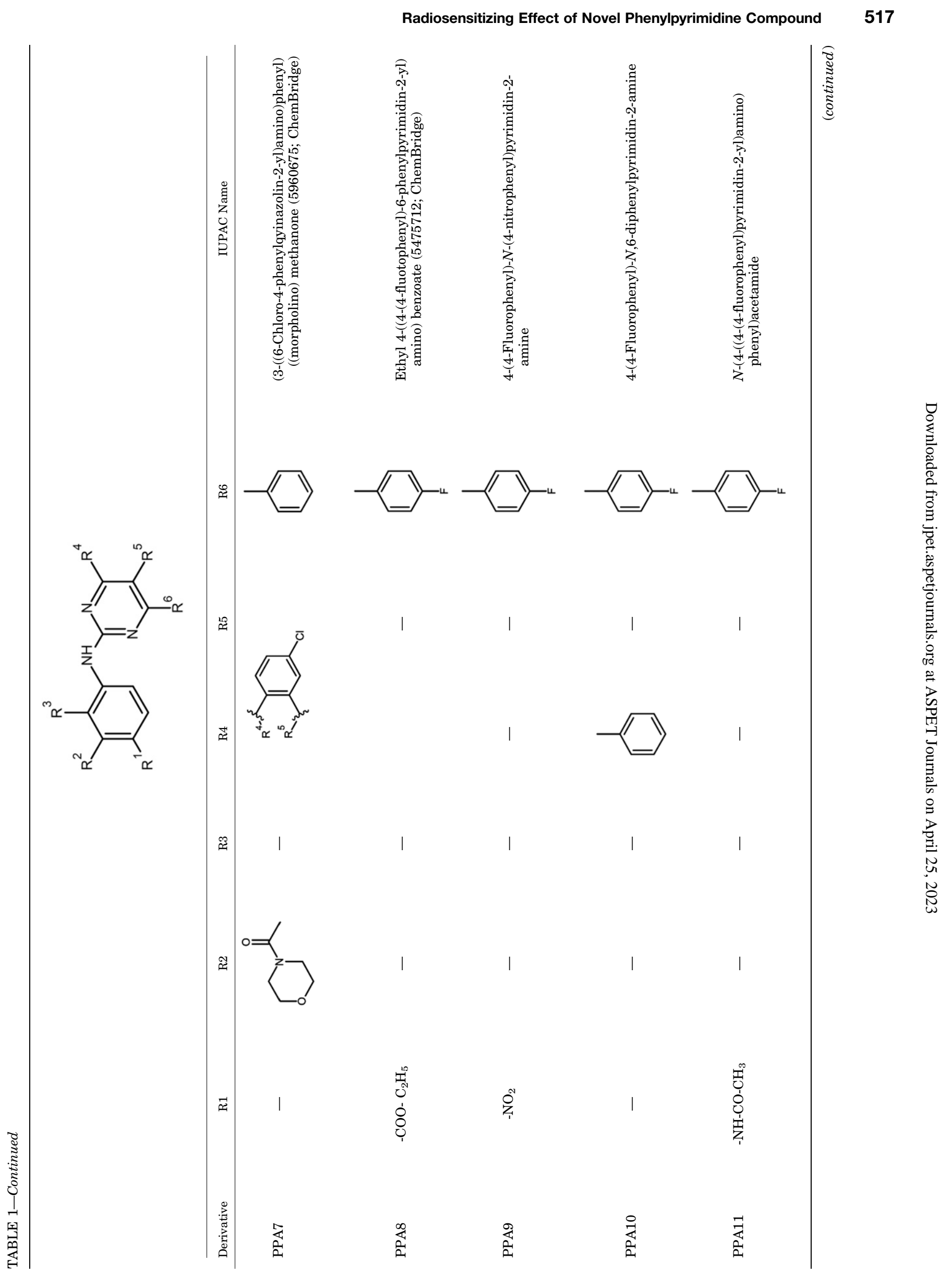




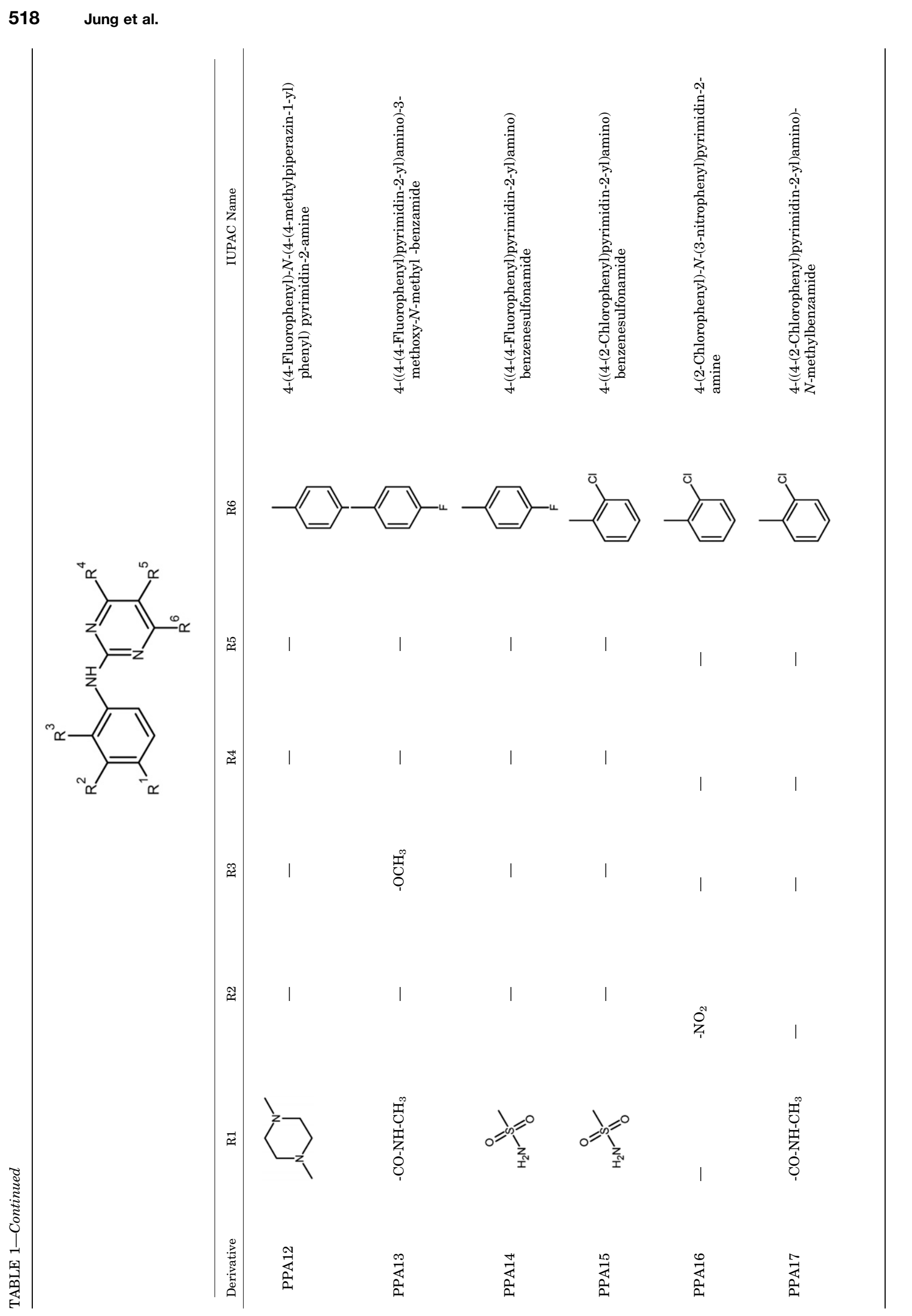


conditions. Cells were harvested and fixed in $75 \%$ ethanol for 1 hour. They were then washed with PBS and resuspended in PBS buffer containing $100 \mu \mathrm{g} / \mathrm{ml}$ RNase A (Sigma-Aldrich) and $50 \mu \mathrm{g} / \mathrm{ml}$ propidium iodide, followed by incubation at $37^{\circ} \mathrm{C}$ for 30 minutes. A minimum of 10,000 events/sample were analyzed by flow cytometry to determine the DNA content. The percentage of singlet cells in each cell cycle stage (sub- $\mathrm{G}_{1}, \mathrm{G}_{0} / \mathrm{G}_{1}, \mathrm{~S}, \mathrm{G}_{2} / \mathrm{M}$, or aneuploid) was analyzed with FlowJo software version 7.2.5.

Clonogenic Assay. Cell survival after irradiation was determined using a clonogenic assay (Dunne et al., 2003). Briefly, cells were seeded on $60-\mathrm{mm}$ tissue culture dishes at various densities, treated with the indicated compounds at $1 \mu \mathrm{M}$ for 24 hours, and then exposed to 3 or 3.5 Gy radiation with a ${ }^{137} \mathrm{Cs}$ gamma irradiator (BioBeam 8000; Gamma-Service Medical GmbH, Leipzig, Germany). After 10-14 days, colonies were fixed and stained with $1.0 \%$ methylene blue in absolute methanol solution for 10 minutes. Colonies larger than $0.1 \mathrm{~mm}$ diameter were scored as surviving colonies. The experiment was performed in triplicate for each cell line.

Kinase Assays. The activity of each compound, at a concentration of $10 \mu \mathrm{M}$ and with an ATP concentration of $10 \mu \mathrm{M}$, was screened against a protein kinase panel of 106 human protein kinases provided by the Eurofins' KinaseProfiler Service (Eurofins Pharma Discovery Services, Dundee, UK). The half-maximal inhibitory concentration $\left(\mathrm{IC}_{50}\right)$ values were calculated from 10-point dose-response curves provided by the Eurofins $\mathrm{IC}_{50}$ Profiler Service.

Western Blot Analysis. Total protein from each cell lines was extracted in TNN buffer (50 mM Tris-Cl, pH 7.4; $1 \%$ NP40; $150 \mathrm{mM}$ $\mathrm{NaCl}$, and $1 \mathrm{mM}$ EDTA) supplemented with protease inhibitors (1 mM phenylmethylsulfonyl fluoride, $1 \mu \mathrm{g} / \mathrm{ml}$ aprotinin, $1 \mu \mathrm{g} / \mathrm{ml}$ leupeptin, and $1 \mathrm{mM} \mathrm{Na} \mathrm{NO}_{4}$ ) and quantified using the Bradford method. Protein samples $(15 \mu \mathrm{g})$ were separated by SDS-PAGE and transferred to a nitrocellulose membrane. After blocking the nonspecific antibody binding sites, the membrane was incubated overnight at $4^{\circ} \mathrm{C}$ with specific antibodies against p-cdc25C (Ser216) (63F9; Cell Signaling Technology, Billerica, MA), cdc25C (5H9; Cell Signaling), p-CDK2 (Thr160) (Cell Signaling), CDK2 (78B2; Cell Signaling), p-cdc2 (p-CDK1) (Y15) (10A11; Cell Signaling), cdc2 (PHO1; Cell Signaling), p-histone H3 (p-HH3) (S10) (D2C8; Cell Signaling), histone H3 (HH3) (Cell Signaling), Cyclin A2 (BF683; Cell Signaling), Cyclin B1 (D5C10; Cell Signaling), p53 (DO-1; Santa Cruz Biotechnology, Santa Cruz, CA), p21 Waf/Cip1 (12D1; Cell Signaling), $\gamma \mathrm{H} 2 \mathrm{AX}$ (Santa Cruz Biotechnology), poly (ADP-ribose) polymerase (PARP) (46D11; Cell Signaling), and $\beta$-actin (Sigma-Aldrich). After incubation with peroxidase-conjugated secondary antibodies at $37^{\circ} \mathrm{C}$ for 1 hour, the protein bands were visualized using enhanced chemiluminescence reagent (GE Healthcare Biosciences, Pittsburgh, PA) and detected using the Amersham Imager 680 (GE Healthcare Biosciences). The relative levels of phosphorylated protein expression were normalized to their corresponding total protein and the relative levels of other protein expression were normalized to $\beta$-actin.

Tumor Xenograft Mouse Models. Female 6-week-old athymic nude $(\mathrm{nu} / \mathrm{nu})$ mice from Orient Bio Inc. (Seongnam, Korea) were housed under specific pathogen-free conditions in microisolator cages with laboratory chow and water ad libitum. A549 cell xenografts were established by implanting $1 \times 10^{6}$ cultured cells subcutaneously into the thigh of the right hind leg of the mice. The tumor site was locally irradiated with 5 Gy ${ }^{60} \mathrm{Co} \gamma$-radiation $(2 \mathrm{~Gy} / \mathrm{min})$ when the tumor volumes reached $100-150 \mathrm{~mm}^{3}$. PPA5 $(10 \mathrm{mg} / \mathrm{kg})$ or PPA15 $(2 \mathrm{mg} / \mathrm{kg})$ was administered intraperitoneally 3 hours before irradiation. The tumor was measured along two axes (L, longest axis; W, shortest axis) with Vernier calipers two or three times per week after irradiation. Tumor volume was calculated as $\left(\mathrm{L} \times \mathrm{W}^{2}\right) / 2\left(\mathrm{~mm}^{3}\right)$. All animal experiments were approved by the Institutional Animal Care and Use Committees of the Korea Institute of Radiologic \& Medical Sciences (KIRAMS 2018-0031).

Statistical Analysis. Statistical analyses were performed using GraphPad software version 5 (GraphPad, La Jolla, CA). All data are expressed as the mean \pm S.D., except for the xenograft assay, where data are expressed as the mean \pm S.E. Significant differences between groups were determined using ANOVA and Bonferroni post-hoc comparisons. A value of $P<0.05$ was considered statistically significant.

\section{Results}

Chemistry. The structures of the PPA derivatives are shown in Table 1. The PPA1-PPA8 compunds were purchased from ChemBridge, and the new PPA derivatives (PPA9PPA17) were synthesized according to the methods outlined in Scheme 1.

Effects of PPA Derivatives on Cell Viability. The 3(4,5-dimethylthiazol-2-yl)-2,5-diphenyltetrazolium bromide assay was used to evaluate in vitro cell viability after incubation with each compound at a fixed concentration of $10 \mu \mathrm{M}$ in A549 human lung cancer cells. Compared with the DMSO control, compounds PPA4, PPA5, and PPA13-PPA17 displayed $>50 \%$ growth inhibition after 72 hours (Fig. 1A). To investigate the inhibitory effect of these compounds on cell growth, asynchronously growing A549 cells were exposed to each compound for 72 hours and cell cycle analysis was performed (Supplemental Table 1). As shown in Fig. 1B, PPA5 and PPA13-PPA17 significantly increased the population of cells in $\mathrm{G}_{2} / \mathrm{M}$. In addition, the population of aneuploidy cells with an abnormal number of chromosomes $(>4 \mathrm{n})$ (Pantazi et al., 2014; Orr et al., 2015) was also increased following treatment with these five compounds, except for PPA5. PPA14 induced the most evident arrest at the $\mathrm{G}_{2} / \mathrm{M}$ phase, with $72.4 \%$ of the cell population in $\mathrm{G}_{2} / \mathrm{M}$; only $9.0 \%$ of cells treated with PPA14 were in the $\mathrm{G}_{0} / \mathrm{G}_{1}$ phase compared with $78.4 \%$ of cells in the DMSO control. In addition, PPA15 significantly increased the proportion of cells in the sub-G $\mathrm{G}_{1}$ phase, an indicator of cell death, from $1.5 \%$ in control cells to 9.8\% (Fig. 1C).

Radiosensitizing Effect of PPA Derivatives. Among the tested PPA derivatives, we selected six compounds (PPA5 and PPA13-PPA17) for further investigation based on the aforementioned findings. Since highly proliferative cancer cells are more susceptible to chemotherapy or radiotherapy during $\mathrm{G}_{2} / \mathrm{M}$ arrest (Guha, 2012), we aimed to determine whether the selected PPA compounds would increase the sensitivity of cancer cells to radiation. Consistent with many earlier findings, irradiation alone increased the proportion of cells in the $\mathrm{G}_{2} / \mathrm{M}$ phase from $15.2 \%$ in the DMSO control to 41.1\% (Supplemental Table 2). PPA5, PPA16, and PPA17 treatment in conjunction with irradiation additively increased the population of cells in $\mathrm{G}_{2} / \mathrm{M}$ arrest after 48 hours, whereas treatment with PPA13-PPA15 alone caused a large population of cells to remain in the $\mathrm{G}_{2} / \mathrm{M}$ phase. Given the results of Fig. $1 \mathrm{C}, \mathrm{G}_{2} / \mathrm{M}$ arrest induced by each PPA5, PPA16, and PPA17 was maintained for 72 hours, while PPA13-PPA15induced $\mathrm{G}_{2} / \mathrm{M}$ arrest occurred early, and released slowly. Interestingly, an increase in the sub- $\mathrm{G}_{1}$ cell population was observed only with a combination of PPA15 and irradiation, suggesting that PPA15 may be the most effective radiosensitizer compound (Fig. 2A; Supplemental Table 2). To further confirm the radiosensitizing effect of the selected compounds, we measured clonogenic survival, which is the most reliable and classic method to determine radiosensitivity (Buch et al., 2012). As shown in Fig. 2, B and C, treatment with PPA13, PPA14, and PPA15 alone increased the cytotoxicity of the 
cells. Moreover, the radiation-induced clonogenic survival of A549 human lung carcinoma cells showed a greater decrease following treatment with PPA14 or PPA15, suggesting that both of these compounds possess radiosensitizing activity.

PPA Derivatives Induce $\mathbf{G}_{2} / \mathbf{M}$ Arrest. To further investigate the molecular mechanism underlying the induction of $\mathrm{G}_{2} / \mathrm{M}$ arrest by the selected PPA derivatives, we measured the levels of proteins involved in the $\mathrm{G}_{2} / \mathrm{M}$ phase progression in p53 wild-type A549 and p53-null H1299 cells (Fig. 3). PPA15 and PPA16 treatment increased the levels of phosphorylated cdc25c (S216) in A549 cells, which is a suppressed state of cdc25c phosphatase function and thus prevents cell

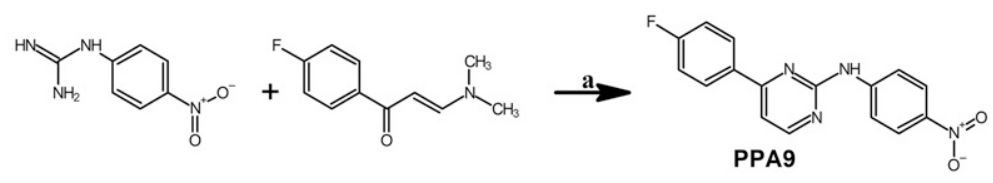

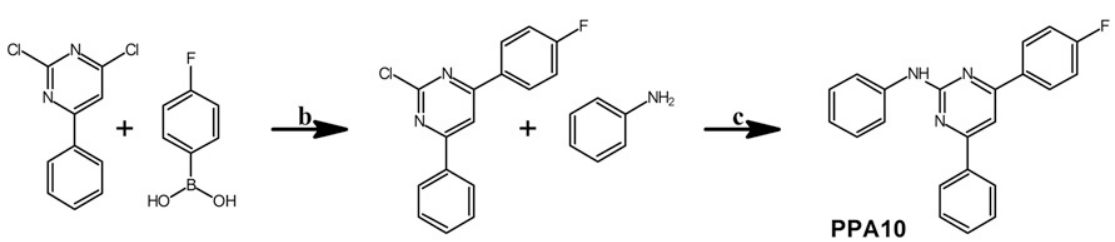

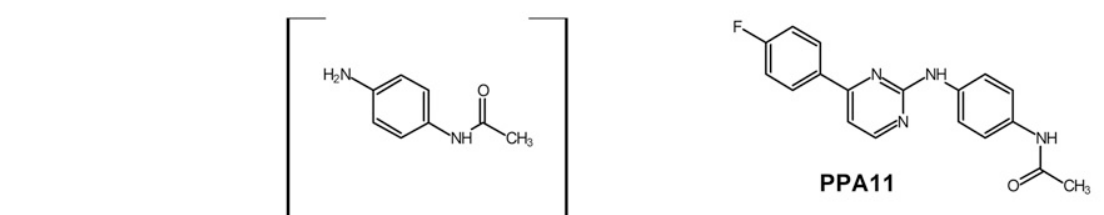<smiles>CN1CCN(c2ccc(Nc3ncc(-c4ccc(F)cc4)nc3Nc3ccc(Nc4ccc(N)cc4)cc3)cc2)CC1</smiles><smiles>CCNC(=O)c1ccc(N)c(OC)c1</smiles><smiles>CNC(=O)c1ccc(Nc2nccc(-c3ccc(F)cc3)n2)c(OC)c1</smiles>

Scheme 1. Synthesis of PPA derivatives; $a=$ $\mathrm{NaOH}$, isopropanol (IPA), reflux; $\mathrm{b}=\mathrm{Pd}(\mathrm{OAc})_{2}$, $\mathrm{Na}_{2} \mathrm{CO}_{3}, \mathrm{PPh}_{3}, \mathrm{THF} / \mathrm{H}_{2} \mathrm{O}, 60^{\circ} \mathrm{C} ; \mathrm{c}=\mathrm{Pd}(\mathrm{OAc})_{2}$, $\mathrm{Cs}_{2} \mathrm{CO}_{3}, 2,2^{\prime}$-bis(diphenylphosphino)-1,1'-binaphthyl (BINAP), dioxane, $100^{\circ} \mathrm{C} ; \mathrm{d}=\mathrm{Pd}(\mathrm{OAc})_{2}, \mathrm{Cs}_{2} \mathrm{CO}_{3}$, BINAP, dioxane, $100^{\circ} \mathrm{C} ; \mathrm{e}=\mathrm{Pd}\left(\mathrm{PPh}_{3}\right)_{4}$, $\mathrm{K}_{2} \mathrm{CO}_{3}, \mathrm{PhMe} / \mathrm{EtOH} / \mathrm{H}_{2} \mathrm{O}, 60^{\circ} \mathrm{C} ; \mathrm{f}=\mathrm{Pd}_{2}(\mathrm{dba})_{3}$, $\mathrm{K}_{2} \mathrm{CO}_{3}$, Xphos, t-BuOH, reflux; $\mathrm{g}=\mathrm{Pd}\left(\mathrm{PPh}_{3}\right)_{4}$, $\mathrm{K}_{2} \mathrm{CO}_{3}, \mathrm{PhMe} / \mathrm{EtOH} / \mathrm{H}_{2} \mathrm{O}, 60^{\circ} \mathrm{C} ; \mathrm{h}=\mathrm{Pd}_{2}(\mathrm{dba})_{3}$

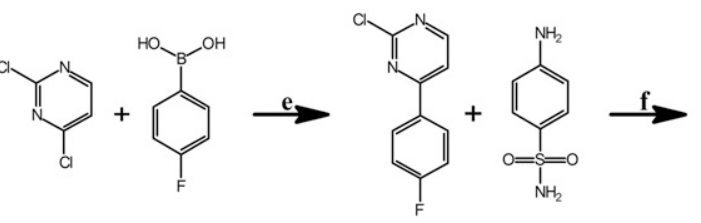<smiles>CC(C)C(C)(N)c1ccc(Nc2nccc(-c3ccc(F)cc3)n2)cc1</smiles>
$\mathrm{K}_{2} \mathrm{CO}_{3}$, Xphos, t-BuOH, reflux.

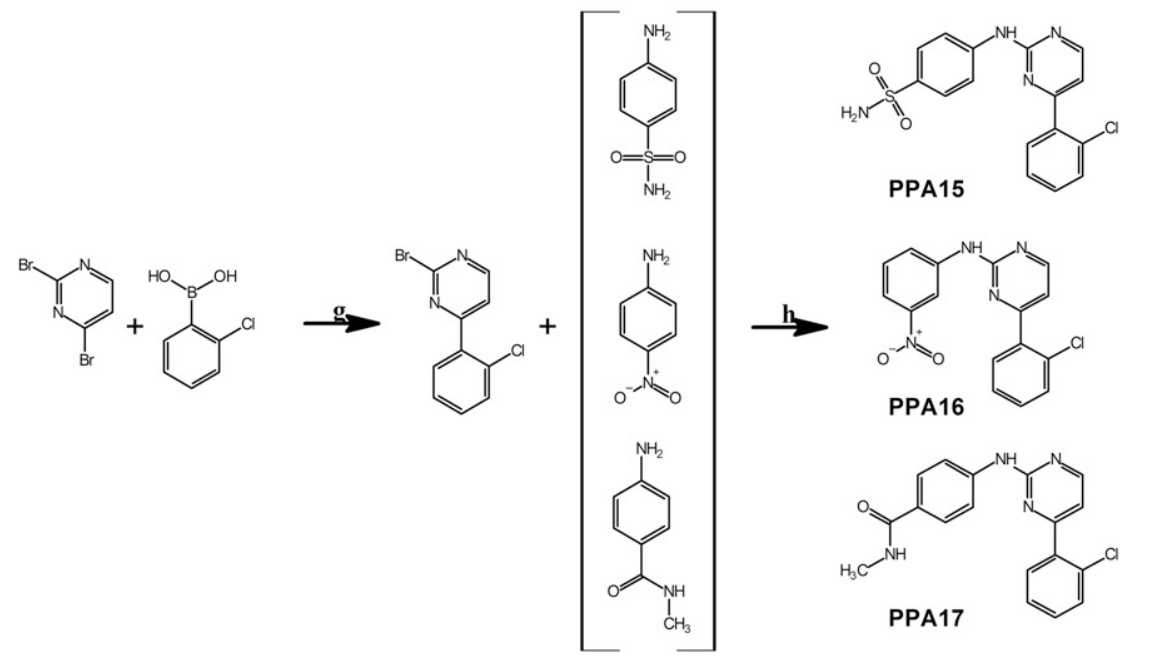


A

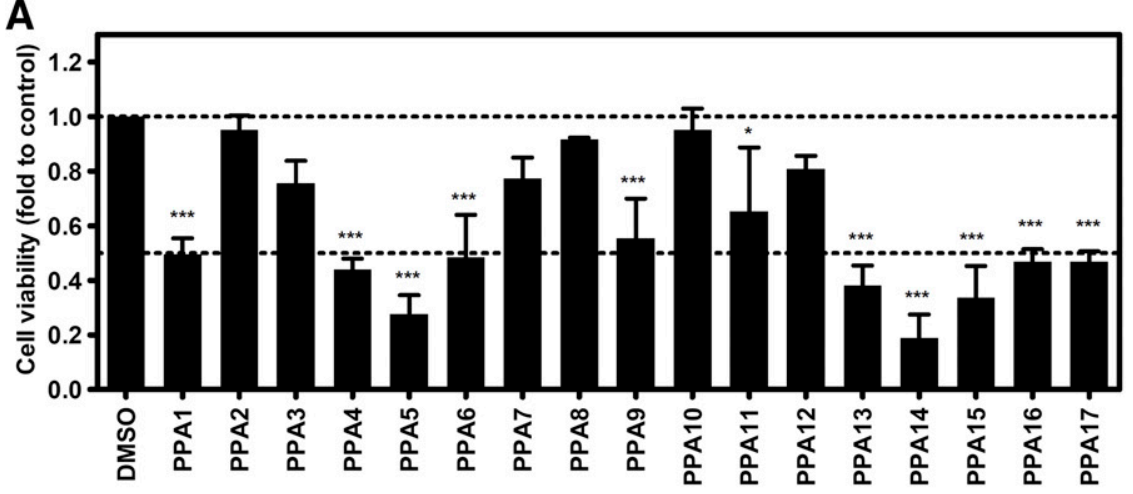

B

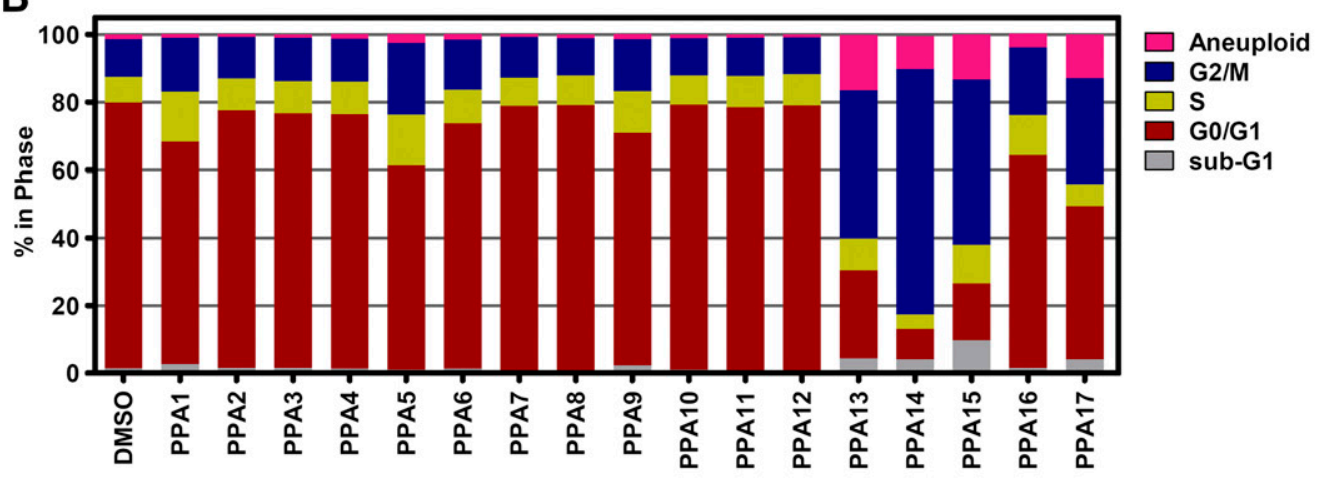

C

DMSO

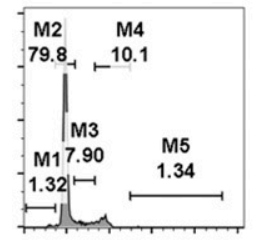

PPA5

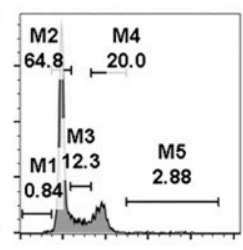

PPA13

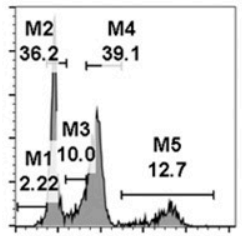

PPA14

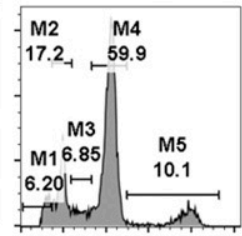

PPA15

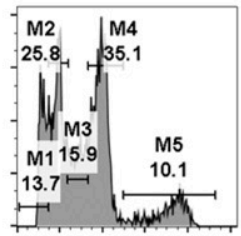

PPA16

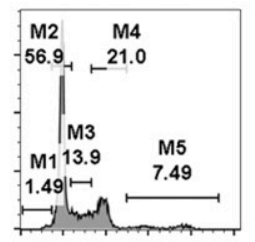

PPA17

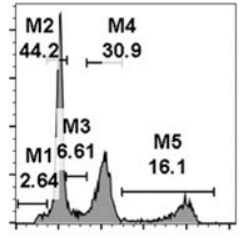

Fig. 1. PPA derivatives can induce $\mathrm{G}_{2} / \mathrm{M}$ arrest. (A) Cell viability of A549 cells at 72 hours after treatment with $10 \mu \mathrm{M}$ PPAs. Data are shown as the mean \pm S.D. of three independent experiments. ${ }^{*} P<0.05$; $* * P<0.01$; ***P $<0.001$. (B) A549 cells were treated with $10 \mu \mathrm{M}$ PPAs for 72 hours and then subjected to cell cycle analysis. Data represent the mean of each cell cycle population from three independent experiments. (C) Histograms of selected PPA compounds based on one representative result of (B). M1: sub- $G_{1}$ phase; $M 2$ : $G_{0} / G_{1}$ phase; M3: S phase; M4: $G_{2} / M$ phase, M5: aneuploid cells.

progression from $\mathrm{G}_{2}$ to mitosis. In addition, increased levels of active CDK2 (T160), inhibitory CDK1 (Y15), cyclin A2, and cyclin B1 expression by PPA14 and PPA15 in both cell lines indicated that cells remained primarily in the $\mathrm{G}_{2}$ phase. In particular, the treatment of PPA14, PPA15, and PPA17 significantly decreased expression of phosphorylated histone $\mathrm{H} 3$, indicating that the cells did not enter the mitotic phase or had already exited the mitotic phase. The levels of p53 in A549 cells were increased by some PPAs, while p21 expression was highly increased in H1299 cells by PPA14 and PPA15 treatment. These results indicate that PPA15 effectively increased the proportion of cells in the $\mathrm{G}_{2} / \mathrm{M}$ phase by modifying the activity of the cyclin/CDK complex in a p53-independent manner.

Antitumor Effect of PPA. To further evaluate the radiosensitivity of PPA15, we measured apoptotic cell death in the presence or absence of p53 function. As shown in Fig. 4A, combined treatment with PPA15 and irradiation significantly increased the population of annexin-positive cells in a p53independent manner. It is well known that p53 and p21 are key regulators of cell cycle arrest and apoptosis, and that both are involved in $\mathrm{G}_{1}$ as well as $\mathrm{G}_{2} / \mathrm{M}$ arrest after irradiation, thereby sensitizing tumor cells to radiation (Iliakis et al., 2003; Jung et al., 2017). As expected, irradiation markedly increased the protein levels of p53 and p21 in p53 wild-type A549 cells, whereas PPA15 did not significantly alter p53/p21 levels, but rather increased the levels of PARP1 cleavage and $\gamma \mathrm{H} 2 \mathrm{AX}$ expression. In p53-null H1299 cells, p21 levels were slightly increased in response to both irradiation and PPA15, either alone or in combination. In addition, PARP1 cleavages and $\gamma \mathrm{H} 2 \mathrm{AX}$ levels were also increased in the same treatment (Fig. 4B). These data suggest that PPA15 may effectively increase radiation-induced cell death via cell cycle perturbation with insufficient DNA damage repair.

Based on these results, the weakest (PPA5) and most active (PPA15) compounds were selected for the evaluation of antitumor effects in an in vivo xenograft mouse model. Mice were administered with $10 \mathrm{mg} / \mathrm{kg}$ PPA5 or $2 \mathrm{mg} / \mathrm{kg}$ PPA15 intraperitoneally 3 hours prior to local irradiation. The body weights of the mice during the whole experiment did not differ significantly between all groups. Compared with the control, PPA5 alone, radiation alone, and combined PPA5 and irradiation treatment inhibited tumor growth by $14.7 \%$, 
A
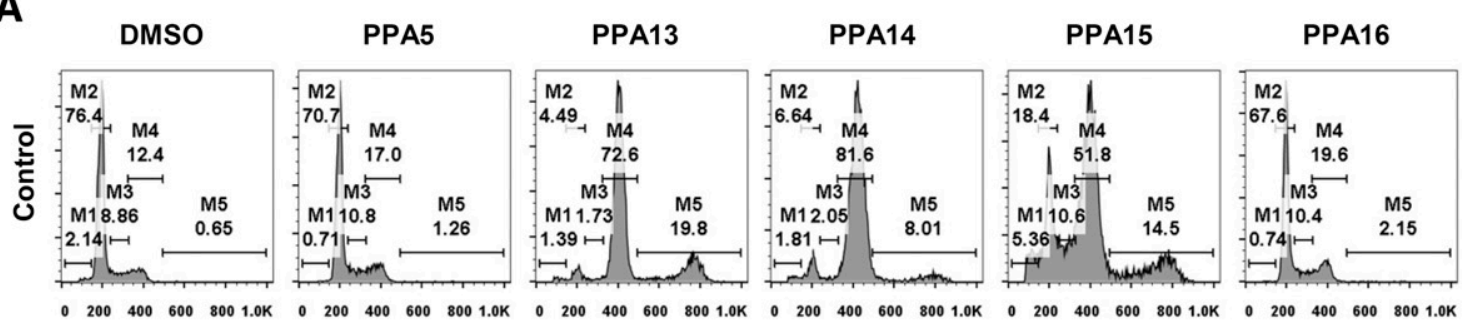

PPA17
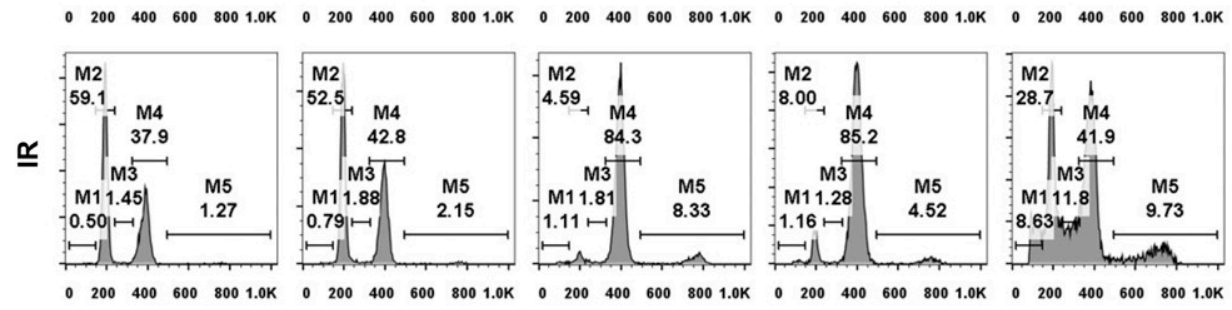

$\begin{array}{llllll}0 & 200 & 400 & 600 & 800 & 1.0 \mathrm{~K}\end{array}$
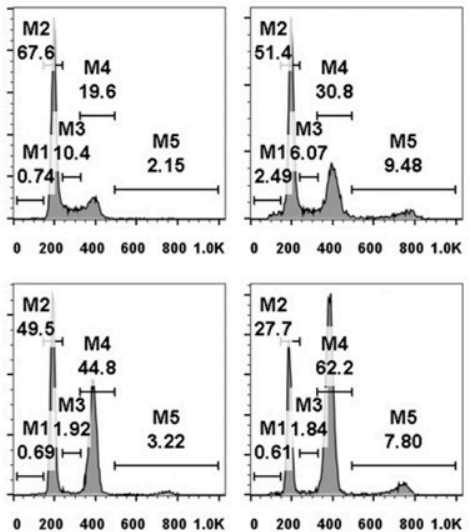

B
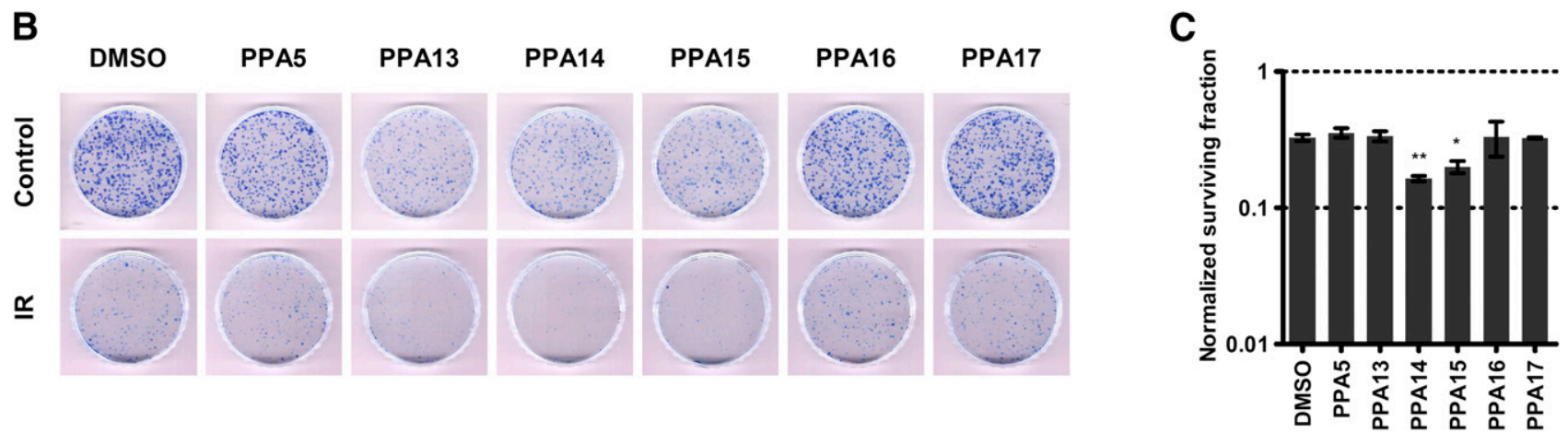

Fig. 2. Selected PPA compounds increase radiosensitivity. (A) Cells were treated with the indicated PPAs (10 $\mu$ M) for 24 hours prior to a 5 Gy dose of $\gamma$-irradiation and subjected to cell cycle analysis after further incubation for 24 hours. One representative result from three independent experiments is shown. M1: sub- $\mathrm{G}_{1}$ phase; $\mathrm{M} 2$ : $\mathrm{G}_{0} / \mathrm{G}_{1}$ phase; M3: S phase; $\mathrm{M} 4: \mathrm{G}_{2} / \mathrm{M}$ phase, M5: aneuploid cells. (B) A549 cells were treated with $1 \mu \mathrm{M}$ PPAs for 24 hours and then exposed to a $3.5 \mathrm{~Gy}$ dose of irradiation. Cells were stained with methylene blue 10 days after irradiation, and representative staining images are shown. (C) Surviving fractions of the cells from (B), as an indicator of radiosensitivity. Data are shown as the mean \pm S.D. of the normalized values for each drug-alone treatment group. ${ }^{*} P<0.05 ; * * P<0.01$.

$36.5 \%$, and $70.9 \%$, respectively (Fig. 4C). PPA15 treatment at $20 \%$ that for PPA5 resulted in 25.7\% tumor inhibition compared with control levels. PPA15 in combination with irradiation inhibited tumor growth more effectively than PPA15 alone or radiation alone, but a synergistic effect was not observed. Despite the insignificant effect on radiosensitivity by PPA15 in the animal study, the clonogenic survival of several irradiated cancer cells, including DU 145 prostates, SKOV3 cervical, U-87 glioma, and MDA-MB-231 breast cancer cells, was significantly decreased by PPA15 at $1 \mu \mathrm{M}$ (Fig. 4D; Supplemental Fig. 1), suggesting the usefulness of PPA15 as an adjuvant for radiotherapy, with broad activity across multiple tumor types.

To identify the target molecule of PPA15, we performed an in vitro kinase assay. In contrast to the nonspecificity of PPA5, PPA15 showed highly selective inhibition of $\mathrm{CDK} /$ cyclin complexes (Table 2). PPA15 majorly inhibited the kinase activity of p25/CDK5, cyclin E/CDK2, cyclin E/CDK3, and cyclin $\mathrm{A} / \mathrm{CDK} 2\left(\mathrm{IC}_{50}\right.$ values of $9,12,18$, and $19 \mathrm{nmol} / \mathrm{l}$, respectively) and was less active against cyclin $\mathrm{B} / \mathrm{CDK} 1$ or cyclin D/CDK4 by at least several fold (Table 3 ).

\section{Discussion}

Although radiotherapy is a crucial and cost-effective strategy for the clinical treatment of cancer (Sharma et al., 2016), its curative effect is not totally reliable. The need to improve the therapeutic outcomes of radiotherapy gives rise to an urgent requirement for the discovery and clinical application of new radiosensitizer drugs. The results of the present study indicate that PPA15 shows great potential as an effective radiosensitizer, via cell cycle perturbation, for use in human cancer treatment.

The cell cycle is inextricably linked to the cellular response to radiation. Radiation-induced single or double strand DNA breaks trigger multiple signaling pathways, including DNA damage responses and the activation of cell cycle checkpoints (Johnson and Shapiro, 2010). In addition, cells in the $\mathrm{G}_{2} / \mathrm{M}$ phase of the cell cycle are approximately three times more radiosensitive than cells in the $\mathrm{S}$ phase (Terasima and Tolmach, 1963). Furthermore, many cancer cells have mutations or deletions in the $p 53$ gene or other p53 signaling pathway defects that impair its role in controlling the $G_{1}$ checkpoint, which leads to a far greater reliance on $G_{2}$ checkpoints than that observed in normal cells (Kawabe, 2004). Therefore, novel compounds could exert radiosensitizing activity by increasing the proportion of tumor cells in a more radiosensitive cell cycle phase (Pauwels et al., 2010). The p53 tumor suppressor protein plays a key role in numerous signaling pathways, including those involved in DNA repair, cell cycle progression, redox systems, inflammation, senescence, apoptosis, and metabolism (Fei and El-Deiry, 
A
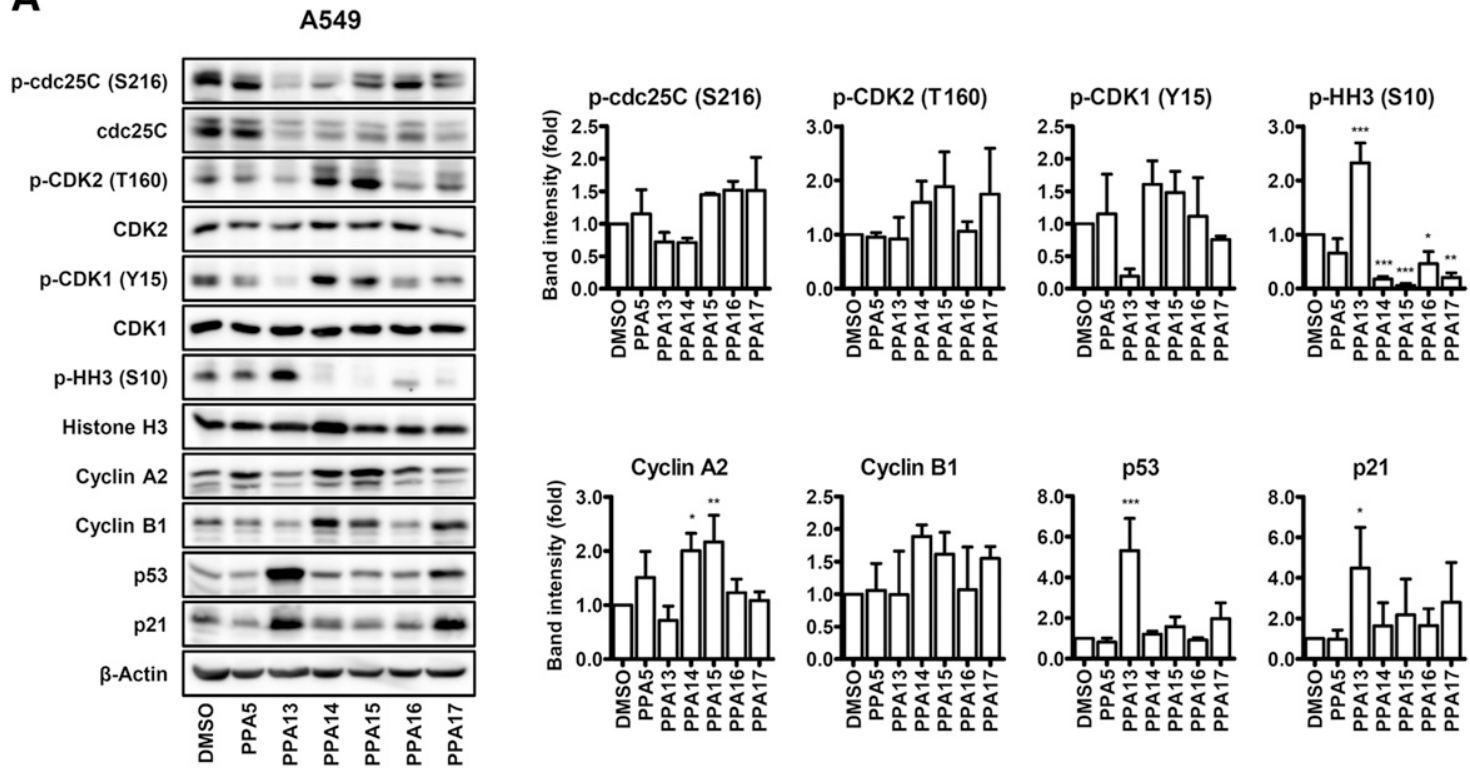

B
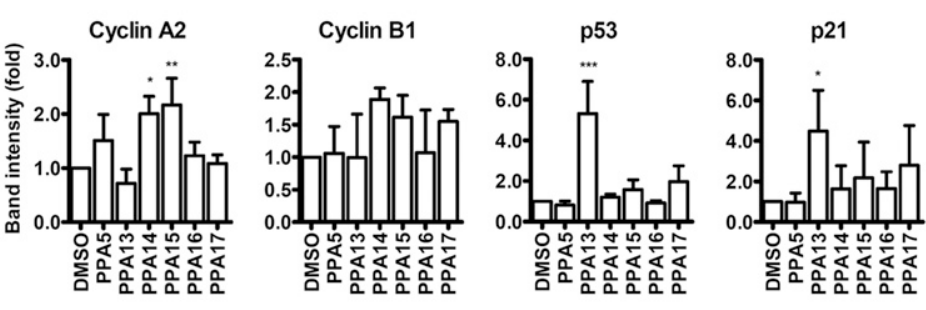

H1299
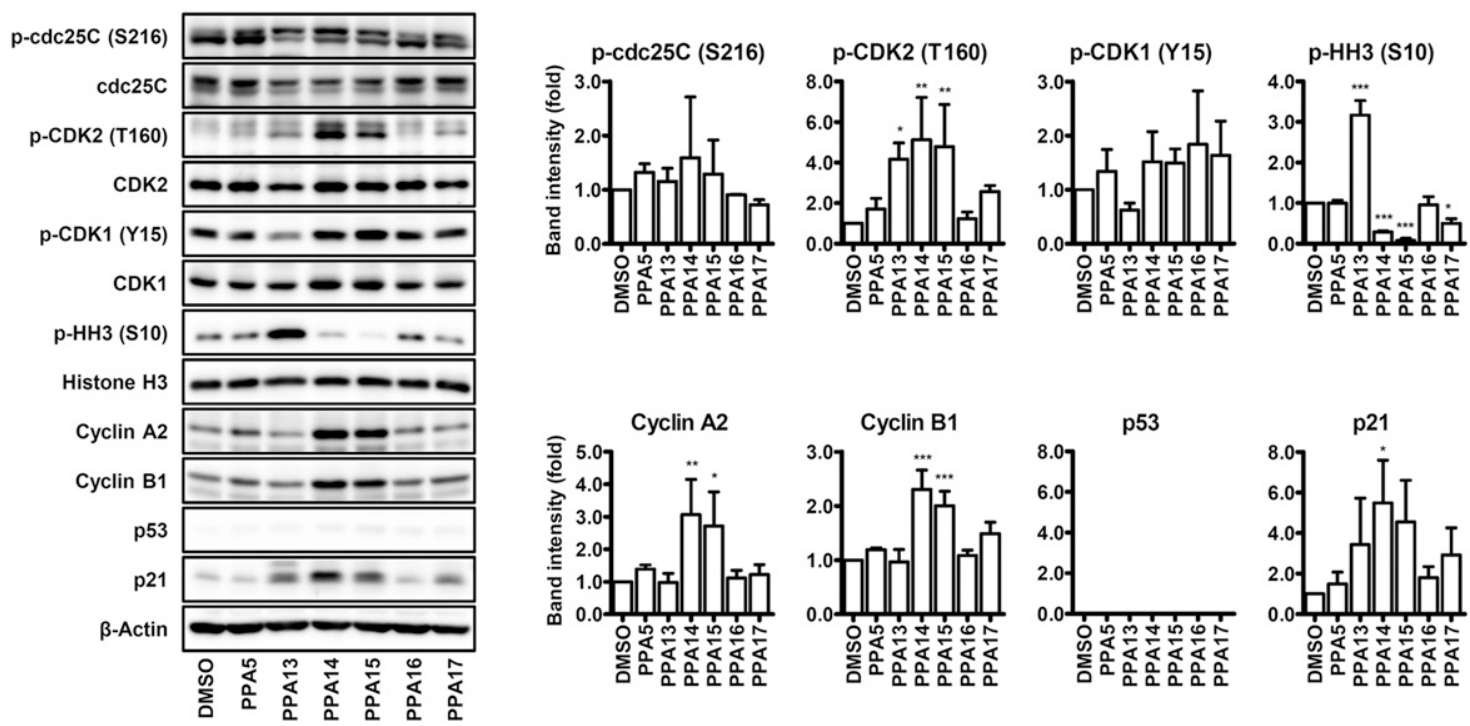

Fig. 3. PPA compounds modulate cell cycle-related protein expression. (A) A549 and (B) H1299 cells were treated with the indicated PPA at $10 \mu \mathrm{M}$ for 48 hours. The levels of the indicated proteins were determined by western blotting and quantified by densitometry using Image $J$ software. One representative result of three independent experiments is shown. The intensities of phosphorylated proteins were normalized by the level of their correspondent total proteins and the intensities of other proteins were normalized by the level of $\beta$-actin. Values are given as the mean \pm S.D. from three independent experiments. ${ }^{*} P<0.05 ; * * P<0.01 ; * * P<0.001$.

2003; Levine and Oren, 2009). The PPA moiety was identified by performing cell-based high-throughput screening to identify novel small molecules that increase radiosensitivity via p53 modulation (Kang et al., 2015). Among the 17 derivatives of PPA investigated, six were selected based on their ability to inhibit cell viability and induce $\mathrm{G}_{2} / \mathrm{M}$ arrest.

The combined treatment of the selected compounds with irradiation more strongly induced $\mathrm{G}_{2} / \mathrm{M}$ arrest than each compound alone, except for PPA15, which stimulated the release of cells from arrest and reentry into the cell cycle. Clonogenic survival analysis of the selected compounds demonstrated that PPA15 was the most effective radiosensitizer. Since distinctive $\mathrm{G}_{2} / \mathrm{M}$ arrest was observed in response to PPA compounds, we examined their effect on the expression of cell cycle-related proteins in two cell lines with different p53 status. The treatment-induced decrease in cyclin A/CDK2 and increase in cyclin B/CDK2 levels allowed cells to enter the $\mathrm{G}_{2}$ phase. Concomitantly, inhibitory cdc25c and CDK1 levels were increased, suggesting that cells were arrested in the M phase without p53 dependency. In addition, the rapid release from $\mathrm{G}_{2} / \mathrm{M}$ arrest by PPA15 and irradiation treatment may have induced cell death, as evidenced by the increase in the apoptotic cell population, PARP1 cleavage, and $\gamma \mathrm{H} 2 \mathrm{AX}$ levels. Finally, the administration of a single dose of PPA15 $(2 \mathrm{mg} / \mathrm{kg})$ significantly inhibited tumor growth in mice; however, the in vivo radiosensitizing effect of PPA15 was weakly observed in this study. Because the effect of candidate compounds in vivo is highly dependent on experimental conditions, optimal PPA15 
A

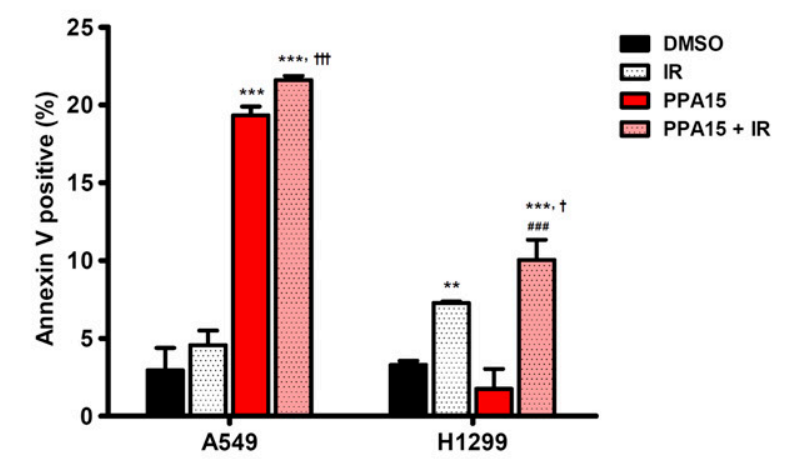

C

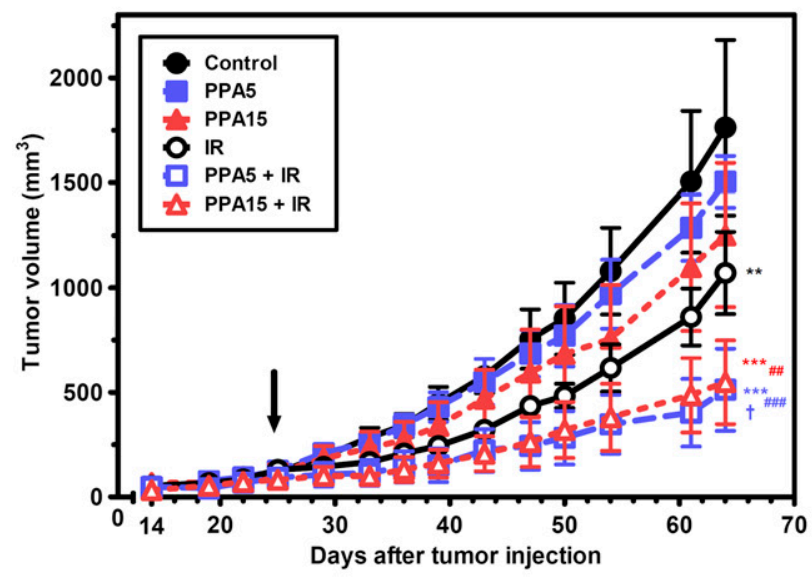

D

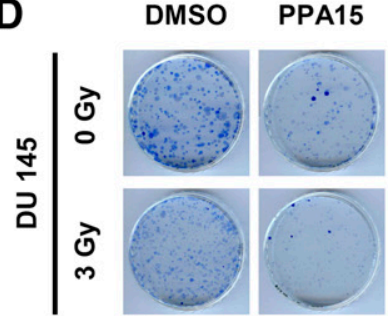

B
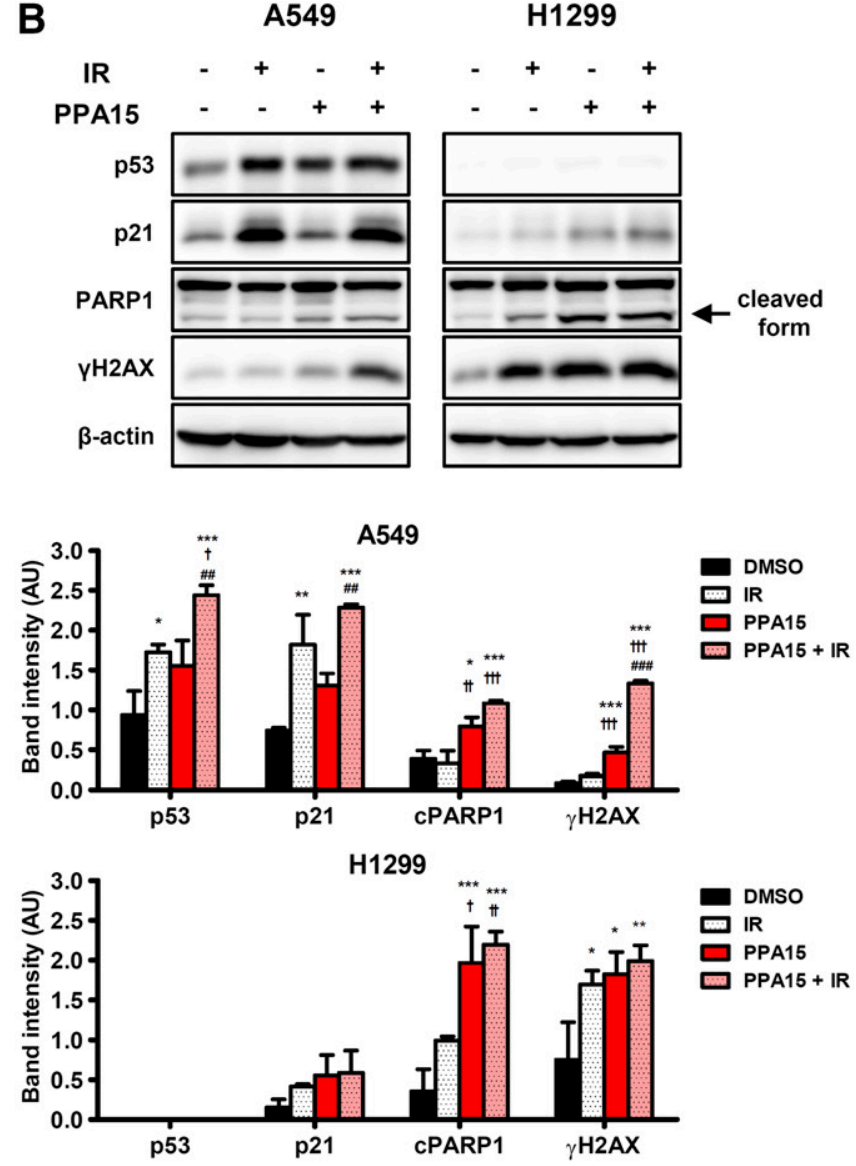

DMSO PPA15

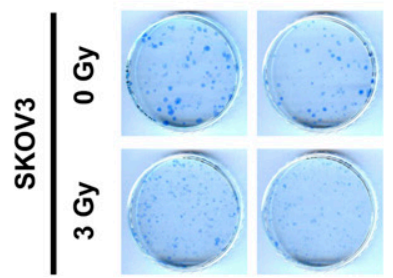

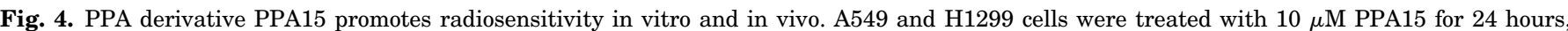

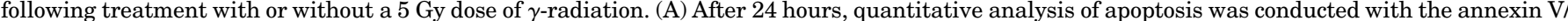

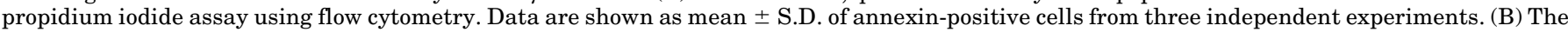

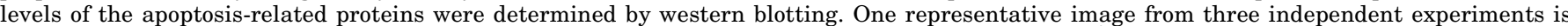

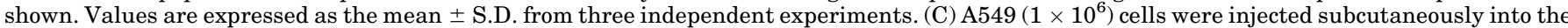

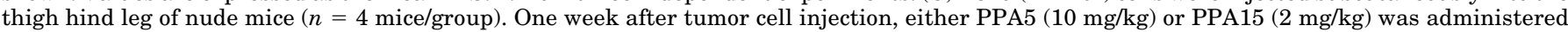

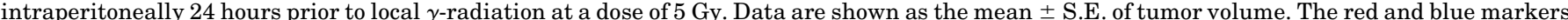

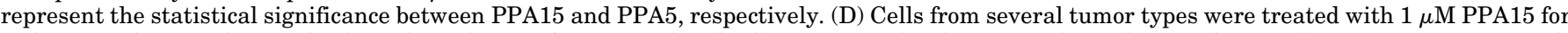

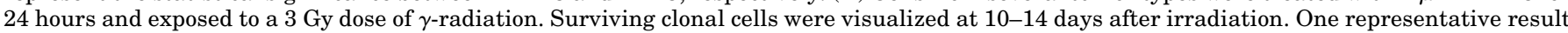

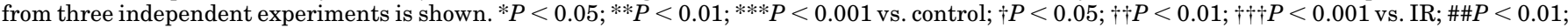
$\# \# \#<0.001$ vs. drug alone.

regimens, including dose, routes of administration, and schedule of the combined irradiation will likely vary for different types of tumors and will have to be determined accordingly. In addition, further pharmacokinetic/pharmacodynamic analysis of PPA15 is required to obtain maximum efficacy.

According to the kinase inhibitory profile of PPA15, most CDK/cyclin complexes were inhibited by PPA15. Thus, PPA15 is considered to be a pan-CDK inhibitor (the $\mathrm{IC}_{50}$ values for CDK1, CDK2, CDK3, CDK5, and CDK9 were in the 10-100 $\mathrm{nM}$ range). The underlying functions of CDK3 and CDK5 are currently unclear. CDK3 is intrinsically important for the entry of cells into the $\mathrm{S}$ phase via activation of transcription factors belonging to the $\mathrm{E} 2 \mathrm{~F}$ family, but its role can be readily compensated by other CDKs (Ye et al., 2001). CDK5 was largely considered a neuronal kinase that protected the nervous system from damage. However, it was recently demonstrated that CDK5 has functions similar to those of CDK4 and CDK2 in driving cell cycle progression from $\mathrm{G}_{1}$ to $\mathrm{S}$ in medullary thyroid cancer models (Pozo et al., 2013). CDK9 is involved in basal transcriptional regulation via the phosphorylation of RNA polymerase II and plays a crucial role in cell growth, proliferation, and differentiation (Romano and Giordano, 2008). 
TABLE 2

Kinase inhibitory effects of the $N$-phenylpyrimidin-2-amine derivatives PPA5 and PPA15

\begin{tabular}{lrr}
\hline \multirow{2}{*}{ Kinase } & \multicolumn{2}{c}{ Kinase Activity } \\
\cline { 2 - 3 } & \multicolumn{1}{c}{ PPA5 $(10 \mu \mathrm{M})$} & $\%$ \\
& $\%$ & $2.16 \pm 0.69$ \\
Aurora-A & $103.32 \pm 9.785$ & $1.14 \pm 0.363$ \\
Aurora-B & $109.57 \pm 2.997$ & $14.89 \pm 3.308$ \\
Aurora-C & $116.56 \pm 6.718$ & $-0.66 \pm 0.526$ \\
CDK1/cyclin B & $96.84 \pm 6.506$ & $0.61 \pm 0.000$ \\
CDK2/cyclin A & $88.08 \pm 1.61$ & $-1.67 \pm 0.074$ \\
CDK2/cyclin E & $92.25 \pm 6.273$ & $-0.08 \pm 0.057$ \\
CDK3/cyclin E & $89.91 \pm 7.894$ & $8.4 \pm 2.752$ \\
CDK4/cyclin D3 & $97 \pm 1.449$ & $0.5 \pm 1.589$ \\
CDK5/p25 & $89.84 \pm 6.544$ & $0.73 \pm 0.693$ \\
CDK5/p35 & $101.66 \pm 1.411$ & $6.06 \pm 0.977$ \\
CDK6/cyclin D3 & $99.34 \pm 4.545$ & $19.89 \pm 2.392$ \\
CDK7/cyclin H/MAT1 & $101.78 \pm 0.406$ & $1.24 \pm 0.115$ \\
CDK9/cyclin T1 & $94.9 \pm 3.752$ & $81.76 \pm 1.968$ \\
CHK1 & $105.62 \pm 0.864$ & $64.19 \pm 3.172$ \\
CHK2 & $97.26 \pm 4.61$ & -1.96 \\
Plk1 & $109.06 \pm 1.546$ & $95.7 \pm 5.397$ \\
Plk3 & $108.67 \pm 1.274$ & $86.53 \pm 6.204$ \\
Wee1 & $99.22 \pm 3.125$ & $91.8 \pm 0.276$ \\
ATM & $92.77 \pm 1.411$ & $93.16 \pm 8.725$ \\
ATR/ATRIP & $97.31 \pm 7.598$ & $74.93 \pm 1.276$ \\
DNA-PK & $92.17 \pm 2.746$ & \\
\hline
\end{tabular}

CDKs are highly validated targets for cancer therapeutics because they play a critical role in the regulation of cell cycle checkpoints and transcription. CDKs are major drug targets, and many CDK inhibitors have been described in the literature. However, because of the functional redundancy of CDKs/ cyclins and their critical roles in normal cellular growth, pharmaceutical strategies to develop multiple-targeting or broad-spectrum CDK inhibitors remains limited, and are being pursued in parallel (Satyanarayana and Kaldis, 2009). Redundant CDKs can easily compensate for the loss of another's function in cancer cells, which provides an acceptable therapeutic margin via differences in their activity in normal cells versus cancer cells (Syn et al., 2018). Therefore, it would be anticipated that simultaneously targeting a range of CDKs is more likely to be therapeutically effective than the selective inhibition of specific CDKs. To date, optimized panCDK or multitarget CDK inhibitors have been extensively investigated, and some clinical benefits have been demonstrated. However, numerous CDK inhibitors have shown

TABLE 3

$\mathrm{IC}_{50}$ values of PPA15 activity against a panel of cyclin-dependent kinases

\begin{tabular}{lc}
\hline \multicolumn{1}{c}{ Kinase } & $\mathrm{IC}_{50}$ \\
\hline & $n M$ \\
CDK1/cyclin B & 53 \\
CDK2/cyclin A & 19 \\
CDK2/cyclin E & 12 \\
CDK3/cyclin E & 18 \\
CDK4/cyclin D3 & 4169 \\
CDK5/p25 & 9 \\
CDK5/p35 & 16 \\
CDK6/cyclin D3 & 1685 \\
CDK7/cyclin H/MAT1 & $>10,000$ \\
CDK9/cyclin T1 & 105 \\
CHK1 & $>10,000$ \\
CHK2 & $>10,000$ \\
\hline
\end{tabular}

disappointing results in clinical trials, possibly owing to an insufficient understanding of their mechanism of action, the absence of biomarkers, and the resulting inappropriate patient selection (Whittaker et al., 2017). Elucidation of the critical targets of these multitarget inhibitors could allow us to better determine the most effective strategy for deploying these agents in a clinical setting (Garrett and Collins, 2011).

Several studies have demonstrated that CDK2, CDK4, and CDK6 are not essential for cell cycle regulation in normal cells (Kozar and Sicinski, 2005; Dean et al., 2010; Sawai et al., 2012). However, CDK1 is known to be required for mammalian cell proliferation, and appears to be a key determinant in stimulating the onset of mitosis (Santamaría et al., 2007). Therefore, inhibitors that target CDK1 frequently lack selectivity for cancer cells over normal tissues and cause problematic effects such as bone marrow suppression, as well as other adverse effects commonly associated with traditional chemotherapy such as nausea, vomiting, and diarrhea (Asghar et al., 2015). For example, the use of Dinaciclib ((S)-3-(( (3-Ethyl-5-(2(2-hydroxyethyl)piperidin-1-yl)pyrazolo[1,5-a]pyrimidin-7-yl) amino)methyl)pyridine 1-oxide; MK-7965), which inhibits CDK1, 2, 5, and 9, has been attempted in patients with leukopenia and thrombocytopenia (Kumar et al., 2015; Mitri et al., 2015). The clinical development of AZD5438 (4-[2Methyl-1-(1-methylethyl)-1H-imidazol-5-yl]-N-[4-(methylsulfonyl)phenyl]-2-pyrimidinamine), which inhibits CDK1, 2, and 9, was discontinued partially because of its low tolerability and high variability in patients (Boss et al., 2010; Prevo et al., 2018). Targeted individual CDK inhibitors could protect normal cells against some cancers, but might have therapeutic value against restricted tumors showing the expression and activation of theses specific CDKs. Nevertheless, selective CDK4/6 inhibitors (Palbociclib, Ribociclib, and Abemaciclib) have been licensed for the treatment of hormone receptorpositive, retinoblastoma-positive breast cancer in combination with antihormonal agents (Hamilton and Infante, 2016). Based on new findings that non-cell cycle-related CDKs are 
associated with cancer in diverse ways, selective inhibitors of CDK5, 7, 8, 9, and 12 have been developed. Moreover, alternative approaches to discovering allosteric sites, proteinprotein interactions, and peptidomimetic mechanisms are also underway to overcoming the selectivity problem for ATPcompetitive agents (Heptinstall et al., 2018).

The narrow therapeutic window of CDK-targeted inhibitors remains a huge obstacle to effective treatment; nevertheless, certain drugs within the correct range of CDK selectivity as well as the combination of CDK1 inhibitors with other targeted therapies continue to be developed (Xia et al., 2014; Whittaker et al., 2017; Wu et al., 2018). Many studies have suggested that CDK inhibitors often do not lead to tumor shrinkage, especially in solid tumors, but rather result in greater cytotoxic effects when used in combination with other chemotherapeutics or radiotherapy (Guha, 2012). Consistent with the aforementioned findings, PPA15 alone directly decreased the tumor volume in A549 xenograft mice, suggesting that it is a promising agent for cancer treatment, either alone or as part of a combination therapy. The use of DNA-damaging chemotherapeutic agents combined with radiotherapy is a common treatment strategy, but many concerns still need to be addressed, including optimizing scheduling, appropriate target selection, improved preclinical models, and biomarkerbased patient selection.

In conclusion, PPA15 treatment induced cell cycle arrest at the $\mathrm{G}_{2} / \mathrm{M}$ phase and enhanced the radiosensitivity of cancer cells via the inhibition of CDK1, CDK2, CDK3, and CDK5. Further studies are needed to establish the optimal sequence and schedule of PPA15 administration in combination with radiotherapy.

\section{Authorship Contributions}

Participated in research design: J.-Y. Song.

Conducted experiments: S.-Y. Jung, J.-I. Park, K.-H. Song.

Contributed new reagents or analytic tools: K.-Y. Nam.Performed data analysis: S.-Y. Jung, J.-I. Park, K.-H. Song, J. Ahn, J. K. Park, H.-D. Um, S.-G. Hwang.

Wrote or contributed to the writing of the manuscript: S.-Y. Jung, K.-Y. Nam, S.U. Choi, J.-Y. Song.

\section{References}

Asghar U, Witkiewicz AK, Turner NC, and Knudsen ES (2015) The history and future of targeting cyclin-dependent kinases in cancer therapy. Nat Rev Drug Discov 14:130-146.

Baumann M, Krause M, Overgaard J, Debus J, Bentzen SM, Daartz J, Richter C, Zips D, and Bortfeld T (2016) Radiation oncology in the era of precision medicine. Nat Rev Cancer 16:234-249.

Boss DS, Schwartz GK, Middleton MR, Amakye DD, Swaisland H, Midgley RS, Ranson M, Danson S, Calvert H, Plummer R, et al. (2010) Safety, tolerability, pharmacokinetics and pharmacodynamics of the oral cyclin-dependent kinase inhibitor AZD5438 when administered at intermittent and continuous dosing schedules in patients with advanced solid tumours. Ann Oncol 21:884-894.

Buch K, Peters T, Nawroth T, Sänger M, Schmidberger H, and Langguth P (2012) Determination of cell survival after irradiation via clonogenic assay versus multiple MTT assay-a comparative study. Radiat Oncol 7:1.

Chi H-C, Tsai C-Y, Tsai M-M, and Lin K-H (2018) Impact of DNA and RNA methylation on radiobiology and cancer progression. Int J Mol Sci 19:555-578.

Dean JL, Thangavel C, McClendon AK, Reed CA, and Knudsen ES (2010) Therapeutic CDK4/6 inhibition in breast cancer: key mechanisms of response and failure. Oncogene 29:4018-4032.

Dunne AL, Price ME, Mothersill C, McKeown SR, Robson T, and Hirst DG (2003) Relationship between clonogenic radiosensitivity, radiation-induced apoptosis and DNA damage/repair in human colon cancer cells. Br J Cancer 89:2277-2283.

Fei P and El-Deiry WS (2003) P53 and radiation responses. Oncogene 22:5774-5783.

Garrett MD and Collins I (2011) Anticancer therapy with checkpoint inhibitors: what, where and when? Trends Pharmacol Sci 32:308-316.

Guha M (2012) Cyclin-dependent kinase inhibitors move into phase III. Nat Rev Drug Discov 11:892-894

Hamilton E and Infante JR (2016) Targeting CDK4/6 in patients with cancer. Cancer Treat Rev 45:129-138.

Harrington KJ, Billingham LJ, Brunner TB, Burnet NG, Chan CS, Hoskin P, Mackay RI, Maughan TS, Macdougall J, McKenna WG, et al. (2011) Guidelines for preclinical and early phase clinical assessment of novel radiosensitisers. $\mathrm{Br}$ $J$ Cancer 105:628-639.

Heptinstall AB, Adiyasa I, Cano C, and Hardcastle IR (2018) Recent advances in CDK inhibitors for cancer therapy. Future Med Chem 10:1369-1388.

Iliakis G, Wang Y, Guan J, and Wang H (2003) DNA damage checkpoint control in cells exposed to ionizing radiation. Oncogene 22:5834-5847.

Johnson N and Shapiro GI (2010) Cyclin-dependent kinases (cdks) and the DNA damage response: rationale for cdk inhibitor-chemotherapy combinations as an anticancer strategy for solid tumors. Expert Opin Ther Targets 14:1199-1212.

Jung S-Y, Kho S, Song K-H, Ahn J, Park I-C, Nam K-Y, Hwang S-G, Nam S-Y, Cho S-J, and Song J-Y (2017) Novel focal adhesion kinase 1 inhibitor sensitizes lung cancer cells to radiation in a p53-independent manner. Int J Oncol 51:1583-1589.

Jung S-Y, Yi JY, Kim M-H, Song K-H, Kang S-M, Ahn J, Hwang S-G, Nam K-Y, and Song J-Y (2015) IM-412 inhibits the invasion of human breast carcinoma cells by blocking FGFR-mediated signaling. Oncol Rep 34:2731-2737.

Kang MA, Kim M-S, Kim JY, Shin Y-J, Song J-Y, and Jeong J-H (2015) A novel pyrido-thieno-pyrimidine derivative activates p53 through induction of phosphorylation and acetylation in colorectal cancer cells. Int J Oncol 46:342-350.

Kawabe $\mathrm{T}(2004) \mathrm{G}_{2}$ checkpoint abrogators as anticancer drugs. Mol Cancer Ther $\mathbf{3}$ : $513-519$.

Kozar K and Sicinski P (2005) Cell cycle progression without cyclin D-CDK4 and cyclin D-CDK6 complexes. Cell Cycle 4:388-391.

Krause M, Yaromina A, Eicheler W, Koch U, and Baumann M (2011) Cancer stem cells: targets and potential biomarkers for radiotherapy. Clin Cancer Res 17: $7224-7229$.

Kumar SK, LaPlant B, Chng WJ, Zonder J, Callander N, Fonseca R, Fruth B, Roy V, Erlichman C, and Stewart AK; Mayo Phase 2 Consortium (2015) Dinaciclib, a novel CDK inhibitor, demonstrates encouraging single-agent activity in patients with relapsed multiple myeloma. Blood 125:443-448.

Lee S, Lim M-J, Kim M-H, Yu C-H, Yun Y-S, Ahn J, and Song J-Y (2012) An effective strategy for increasing the radiosensitivity of human lung cancer cells by blocking Nrf2-dependent antioxidant responses. Free Radic Biol Med 53:807-816.

Levine AJ and Oren M (2009) The first 30 years of p53: growing ever more complex. Nat Rev Cancer 9:749-758.

Lim M-J, Ahn J-Y, Han Y, Yu C-H, Kim M-H, Lee S-L-O, Lim D-S, and Song J-Y (2012) Acriflavine enhances radiosensitivity of colon cancer cells through endoplasmic reticulum stress-mediated apoptosis. Int $J$ Biochem Cell Biol 44: $1214-1222$.

Malumbres M and Barbacid M (2001) To cycle or not to cycle: a critical decision in cancer. Nat Rev Cancer 1:222-231.

Mitri Z, Karakas C, Wei C, Briones B, Simmons H, Ibrahim N, Alvarez R, Murray JL, Keyomarsi K, and Moulder S (2015) A phase 1 study with dose expansion of the CDK inhibitor dinaciclib (SCH 727965) in combination with epirubicin in patients with metastatic triple negative breast cancer. Invest New Drugs 33:890-894.

O'Leary B, Finn RS, and Turner NC (2016) Treating cancer with selective CDK4/6 inhibitors. Nat Rev Clin Oncol 13:417-430.

Orr B, Godek KM, and Compton D (2015) Aneuploidy. Curr Biol 25:R538-542.

Pantazi E, Gemenetzidis E, Trigiante G, Warnes G, Shan L, Mao X, Ikram M, Teh M-T, Lu Y-J, and Philpott MP (2014) GLI2 induces genomic instability in human keratinocytes by inhibiting apoptosis. Cell Death Dis 5:e1028.

Pauwels B, Wouters A, Peeters M, Vermorken JB, and Lardon F (2010) Role of cell cycle perturbations in the combination therapy of chemotherapeutic agents and radiation. Future Oncol 6:1485-1496.

Petersen C, Zips D, Krause M, Schöne K, Eicheler W, Hoinkis C, Thames HD, and Baumann M (2001) Repopulation of $\mathrm{FaDu}$ human squamous cell carcinoma during fractionated radiotherapy correlates with reoxygenation. Int $J$ Radiat Oncol Biol Phys 51:483-493.

Pozo K, Castro-Rivera E, Tan C, Plattner F, Schwach G, Siegl V, Meyer D, Guo A Gundara J, Mettlach G, et al. (2013) The role of Cdk5 in neuroendocrine thyroid cancer. Cancer Cell 24:499-511.

Prevo R, Pirovano G, Puliyadi R, Herbert KJ, Rodriguez-Berriguete G, O'Docherty A Greaves W, McKenna WG, and Higgins GS (2018) CDK1 inhibition sensitizes normal cells to DNA damage in a cell cycle dependent manner. Cell Cycle 17: 1513-1523.

Romano G and Giordano A (2008) Role of the cyclin-dependent kinase 9-related pathway in mammalian gene expression and human diseases. Cell Cycle 7: 3664-3668.

Santamaría D, Barrière C, Cerqueira A, Hunt S, Tardy C, Newton K, Cáceres JF, Dubus P, Malumbres M, and Barbacid M (2007) Cdk1 is sufficient to drive the mammalian cell cycle. Nature 448:811-815.

Satyanarayana A and Kaldis P (2009) Mammalian cell-cycle regulation: several Cdks, numerous cyclins and diverse compensatory mechanisms. Oncogene 28: 2925-2939.

Sawai CM, Freund J, Oh P, Ndiaye-Lobry D, Bretz JC, Strikoudis A, Genesca L, Trimarchi T, Kelliher MA, Clark M, et al. (2012) Therapeutic targeting of the cyclin D3:CDK4/6 complex in T cell leukemia. Cancer Cell 22:452-465.

Sharma RA, Plummer R, Stock JK, Greenhalgh TA, Ataman O, Kelly S, Clay R, Adams RA, Baird RD, Billingham L, et al.; NCRI CTRad Academia-Pharma Joint Working Group (2016) Clinical development of new drug-radiotherapy combinations. Nat Rev Clin Oncol 13:627-642.

Sherr CJ, Beach D, and Shapiro GI (2016) Targeting CDK4 and CDK6: from discovery to therapy. Cancer Discov 6:353-367.

Syn NL, Lim PL, Kong LR, Wang L, Wong AL, Lim CM, Loh TKS, Siemeister G, Goh BC, and Hsieh WS (2018) Pan-CDK inhibition augments cisplatin lethality in nasopharyngeal carcinoma cell lines and xenograft models. Signal Transduct Target Ther 3:9.

Terasima T and Tolmach LJ (1963) Variations in several responses of HeLa cells to $\mathrm{x}$-irradiation during the division cycle. Biophys $J$ 3:11-33.

Whittaker SR, Mallinger A, Workman P, and Clarke PA (2017) Inhibitors of cyclindependent kinases as cancer therapeutics. Pharmacol Ther 173:83-105. 
Wu CX, Wang XQ, Chok SH, Man K, Tsang SHY, Chan ACY, Ma KW, Xia W, and Cheung TT (2018) Blocking CDK1/PDK1/ $\beta$-Catenin signaling by CDK1 inhibitor RO3306 increased the efficacy of sorafenib treatment by targeting cancer stem cells in a preclinical model of hepatocellular carcinoma. Theranostics 8: 3737-3750.

Xia Q, Cai Y, Peng R, Wu G, Shi Y, and Jiang W (2014) The CDK1 inhibitor RO3306 improves the response of BRCA-proficient breast cancer cells to PARP inhibition. Int $J$ Oncol 44:735-744.

Yaromina A, Kroeber T, Meinzer A, Boeke S, Thames H, Baumann M, and Zips D (2011) Exploratory study of the prognostic value of microenvironmental parameters during fractionated irradiation in human squamous cell carcinoma xenografts. Int J Radiat Oncol Biol Phys 80:1205-1213.

Ye X, Zhu C, and Harper JW (2001) A premature-termination mutation in the Mus musculus cyclin-dependent kinase 3 gene. Proc Natl Acad Sci USA 98:1682-1686.

Address correspondence to: Jie-Young Song, Division of Radiation Biomedical Research, Korea Institute of Radiological \& Medical Sciences, 75 Nowon-ro, Nowon-gu, Seoul 01812, Republic of Korea. E-mail: immu@ kirams.re.kr 